\title{
Hadis ve Sünnetin Halka Arzı Sorunu ve Bazı Öneriler
}

\section{The Problem Presenting Hadith and Sunnah to Public and Some Suggestions}

\section{Yusuf Acar}

Doç. Dr., Selçuk Üniversitesi, Íslami İlimler Fakültesi, Hadis Anabilim Dalı

Assoc. Prof., Selcuk University, Faculty of Islamic Studies, Hadith Department

Konya / Turkey

yusuf.acar@selcuk.edu.tr | https://orcid.org/0000-0001-7579-5264

Article Type / Makale Tipi

Research Article / Araștırma Makalesi

DOI: $10.33420 /$ marife.1007852
Article Information / Makale Bilgisi

Received / Geliş Tarihi: 10.10.2021

Accepted / Kabul Tarihi: 29.11.2021

Published / Yayın Tarihi: 30.12.2021

Cite as / Atıf: Acar, Yusuf. "Hadis ve Sünnetin Halka Arzı Sorunu ve Bazı Öneriler”. Marife 21/2 (2021): 833-869. https://doi.org/10.33420/marife.1007852

Plagiarism / Intihal: This article has been reviewed by at least two referees and scanned via a plagiarism software. / Bu makale, en az iki hakem tarafından incelendi ve intihal içermediği teyit edildi.

\section{(c) $(1)$}

Copyright / Telif Hakkl: "This article is an open access article distributed under the terms and conditions of the Creative Commons Attribution-NonCommercial-NoDerivatives 4.0 (CC BY-NC-ND 4.0) International License." / "Bu makale Creative Commons Alıntı-GayriTicari-Türetilemez 4.0 (CC BY-NCND 4.0) Uluslar arası Lisansı altında lisanslanmıștır."

e-ISSN : 2630-5550

www.marife.org 


\section{Hadis ve Sünnetin Halka Arzı Sorunu ve Bazı Öneriler}

Özet

Son dönemlerde hadisin ve/veya Sünnet'in çağa taşınması, asrın idrakine söyletilmesi ya da aktüel hale getirilmesi gibi isimlendirmelerle ortaya konan çabaların ve çalıșmaların, birisi taşınacak olanın neliği ve diğeri de nasıl taşınacağı olmak üzere iki yönü bulunmaktadır. Kütüb-i sitte başta olmak üzere temel hadis kitapları ve bunlar etrafında oluşan hadis ve sünnete dair devasa literatür büyük oranda "hadis-sünnetin neliği" ile ilgili olup günümüz diliyle akademik çalışmalardan oluşmaktadır. İlm-i hadisin tarihini, terminolojisini ve literatürünü okumayanların, tercümeleri vasıtasıyla -ki tercümelerini doğru ve faydalı bulmuyoruz- söz konusu eserleri doğru anlama imkanları yok denecek kadar azdir.

İslami ilimlerin diğer dallarında olduğu gibi ilm-i hadisin de dinin temel maksadına muvafık olarak nihai hedefinin insanların dünyada ve ahirette huzurunu temin etmek olduğunda şüphe yoktur ki bu da Sünnet'in çağa nasıl taşınacağı sorununu gündeme getirmektedir. Son yıllarda birden fazla uluslararası kuruluşça düzenli bir şekilde yayımlanan yolsuzluk endekslerinde İslam dünyasının hiç de parlak olmayan durumu, bu nihâî gaye için ciddi yeni çalışmaların yapılmasını zorunlu kılmaktadır. Bu maksadın gerçekleşebilmesi için ister hadis ve sünnetin aktüel değeri denilsin, ister sünnetin çağa yakınlaştırılması ya da taşınması densin ve isterse asrın idrakine sünnetin söyletilmesi veya sunulması densin okulda öğrencileri, camide cemaati ve cami dışı farklı faaliyetlerde ya da sosyal medya mecralarında halkı Hz. Peygamber'in örnekliğiyle ve rehberliğiyle bulușturmaya çalıșan (tıbbi ifadeyle) pratisyenlere başucu veya el kitabı olabilecek çalıșmalara ihtiyaç vardır. Bu tür çalışmalar, akademik literatürde üretilmiş soyut hedefleri somut hale getirmek suretiyle öğretimi doğrudan yönlendiren ve öğretmenin bulunmadı̆̆ durumlarda onun görevini yerine getiren ders kitapları gibi merkeze ortalama okurları almalıdır. Dil sorunundan ayrı olarak, klasik kaynakların tercümeleri ile belirli bir kitap üzerine yapılan çağdaş birkaç şerhin bahis konusu niteliği haiz olmadığı açıktır. Diyanet İşleri Başkanlığınca özgün, kolektif ve konulu ilk çağdaş hadis șerhi olarak hazırlanan Hadislerle İslam'ın mezkûr ihtiyacın karşılanmasında çok büyük bir adım olduğu inkâr olunamaz. Hatta Hz. Peygamber'in örnekliğinin ve rehberliğinin günümüze nasıl taşınacağı ve geniş halk kitlelerine nasıl sunulacağı ve davranışlara dönüştürüleceği sorununa hedef kitle olarak sevâd-ı azamı teşkil eden ortalama okurları seçerek çare olmak üzere somut olarak ortaya konan yegâne çalışma Hadislerle İslam'dır. Gerek sahip olduğu evsaf itibariyle çağdaş dönemde telif edilen ilk çalışma olan bu eserin gerekse bundan sonra telif edilecek benzer kitapların daha faydalı hale gelebilmesine yönelik mütevazi katkılarımızı birkaç madde halinde sunmak istiyoruz.

a. Öncelikle hicri ilk asırlardaki ehl-i re'y ile ehl-i amel ekollerinin yaptığı gibi hadis-sünnet ayırımına gidilmeli, ortalama okurlara hadisten ziyade kısaca Hz. Peygamber'in örnekliği ve rehberliği diyebileceğimiz Sünnet arz edilmeli, hadis ise bu sünnetin sonraki nesillere taşıyıcısı ya da sünnetin veri tabanı ve ham bilgi deposu mesabesinde görülerek uzmanlarının değerlendirmelerine bırakılmalıdır. Çünkü hadisler, hadis, rivayet, ravi, sahih, zayıf, mevzu '/uydurma gibi tamamen teknik terimler kullanılmadan aktarılamayacağından herhangi bir dini ilim altyapısı olmayan insanlar hadislerle karşı karşıya getirilmeden ve de Hz. Peygamber'i örnek alma ve ona uyma konusunda hadisin referansına muhtaç etmeden doğrudan ve yalnızca Sünnet'in idraklere sunulmasına gayret edilmelidir. Söz ISSı Rasûl-i Ekrem'in (sav) sıhhati ve delaleti sarih olan cevâmi'u'l-kelim nitelikli ve hikmet dolu ya da doğrudan bir sünneti ifade eden hadislerinin arzıyla yetinilmelidir. Ayrıca her ne kadar klasik kaynaklarda mevzu hadis ifadesi kullanılıyor olsa da ihtiyaç miktarınca hadislerin halka arzında uydurma hadis yerine uydurma rivayet tabirinin tercih edilmesinin daha doğru olacağını belirtmek isteriz. Bu meyanda Hadislerle İslam adlandırması, muhtevası bir tarafa en azından söylem olarak, Ayetlerle İslam ve modern selefilik gibi farklı anlayışlara meșruiyet kazandırabileceğinden sorunlu olup bu gibi hadis vurgulu adlandırmalardan kaçınmak gerekir.

b. Mehabet ve bütünlük açısından müekked-gayr-i müekked sünnet, farz/vacip-sünnet, bağlayıcı olanolmayan sünnet gibi kategorik ve iltibasa müsasit değerlendirmeler ulemanın mütalaasına terkedilmeli, halka arzda tıpkı ilk nesillerde olduğu gibi hem mendubu/nafileyi ve vacibi/farzı içine alacak şekilde hem de bağlayıcılık sorunu giderilmiş bir vaziyette Sünnet'in bir zihniyet ve dünya görüşü olarak takdimi sağlanmalıdır.

c. Fetva-takvâ, hukukilik-kanunilik ya da helallik-yasallık gibi çağımızın ciddi dilemmasından sıyrlabilmek için Sünnet'in arzında, örneğin ibadetlerin bedene taalluk eden suretlerini fikıh kitaplarına ve mânevî ya da bâtinî boyutlarını da tasavvufî eserlere bırakıp daha ziyade rivayet 
merkezli bir terğîb-terhîb muhtevalı șerh-yorum takip etmek yerine, Ahmed Yesevî́den Mevlânâ'ya Anadolu irfan geleneğinin şekil-mânâ ve sûret-ruh dengeli anlayıșı benimsenmelidir.

d. Sünnet'in halka arzı esas itibariyle bir eğitim-öğretim faaliyeti olduğundan büyük oranda soyut kavramlardan oluşan adalet, dürüstlük, kul hakkı ve takva gibi değerler ve erdemler, Kur'ân ve Sünnet'in temel anlatım üslupları arasında yer alan somutlaştırma ve kozmik temellendirme üslubuyla izah edilmelidir.

e. Ergenlik dönemi sonuna kadar çocukların ögrreniminin somut olaylar-olgular üzerinden gerçekleștiği dikkate alınarak tıpkı Bibel für Kinder gibi Batı'da hazırlanan ve bir benzerini Çocuklar İçin Açıklamalı Kur'ân adıyla Abdulwahid van Bommel'in yaptığı tarzda somutlaştırma üslubuna dayalı Çocuklar İçin Sünnet kitapları telif edilmelidir.

Anahtar Kelimeler: Hadis, Sünnet, Halka arz, Kategorize, Somutlaştırma.

\section{The Problem Presenting Hadith and Sunnah to Public and Some Suggestions}

\section{Summary}

The efforts and studies that have been made recently under some names such as bringing the hadith and/or the Sunnah nearer to the age, making it say something to the understanding of the century or making it actual, has two aspects: one is what is to be transferred and the other is how it will be done. The main hadith books, especially Kutub-i sitta, and the enormous literature on hadith and sunnah formed around them are mostly about "what the hadith-sunnat is" and consist of academic studies in today's language. Including the commentaries, these contain the information that the scholars will convey to each other and a certain scientific infrastructure is needed to benefit from it. Those who do not read the history, terminology and literature of science hadith science have little or no chance of understanding the works in question through their cmmentaries, which we do not find correct and useful.

It is unquestionable, as in other branches of Islamic sciences, that the ultimate aim of science of hadith, in accordance with the main purpose of religion, is to ensure the peace of people in this world and in the hereafter, which brings up the problem of how the Sunnah will be carried into the era. The not so bright situation of the Islamic world displayed in the corruption indices published regularly by more than one international organization in recent years necessitates serious new studies for this ultimate goal. In order for this purpose to be realized, whether it is called the actual value of hadith and sunnah, or bringing the sunnah closer to the modern age or conveying it to the age, or presenting and making the sunna say something to the understanding of the century, there is a need for studies that can be a bedside or handbook for (in medical terms) practitioners who will make the students at school, the congregation in the mosques, and the people in different activities outside the mosques or in social media acquainted with the exemplary personality and guidance of the Prophet. just like the limited number of works written in the past in the style of Riyâdu's-sâlihîn, put aside their sufficiency, this type of studies should embody the abstract objectives produced in academic literature, orient the teaching directly, and take average readers to the center like the textbooks which fill the gap when there is no teacher. Apart from the language problem, it is clear that the translations of classical sources and a few contemporary commentaries on a particular book do not have the qualification in question. It cannot be denied that the book Islam with hadiths, prepared by the Directorate of Religious Affairs as the first original, collective, and themed contemporary hadith commentary, is a great step forward in meeting the aforementioned need of Islam. The only study put forward concretely as a solution by choosing the average people who constitute the mass of readers, savad-I Azam, whom the exemplary life style and guidance of the prophet will be transferred to and transformed into behaviors is Islam with Hadiths. We would like to specify our modest suggestions to make this work, the first work compiled in the contemporary period in terms of its quality, and similar works to be compiled in the future more useful.

a. First of all, a distinction should be made between hadith and sunnah, as the ahl-i re'y and the ahl-i amel schools did in the first centuries of Hijri; the Sunnah, which we can call the exemplary life style and guidance of the Prophet, rather than the hadith should be presented to the average readers; and the hadith should be seen as the carrier of this sunnah for the next generations, or as the database and raw information repository of the sunnah, and be left to the judgment of experts. Since hadiths cannot be conveyed without using technical terms such as hadith, narration, narrator, sound, weak, 
fabricated, etc., the people who do not have any religious knowledge background should not be confronted with hadiths and they should be directly presented only the sunna without leaving them look for references to take the Prophet as a model and to follow him. It should be contented with the presentation of the hadiths of the Rasul al-Akram (pbuh), full of wisdom, authentic, and with the quality of cavâmiu'l-kalim and whose authenticity and indication are are not disputed. Although the expression of fabricated hadith is used in classical sources, we would like to state also that it would be more appropriate to prefer the term fabricated rivayat instead of fabricated hadith in presenting it whenever a hadith is needed.

In this context, apart from its content, since the title Islam with Hadith is problematic because it can give legitimacy to different understandings such as Islam with Verses and modern Salafism, at least as a discourse, such hadith-emphasizing namings should be avoided.

b. Categorical and confusing evaluations such as muakkad-unmuekked-sunnah, fard/wajib-sunnat, binding and non-binding sunnah should be left to the scholars' comments in terms of dignity and integrity. In the public offering, the Sunnah should be presented as a mentality and worldview in a way that includes both mandub/nafila (supererogatory) and vajib/fard, as in the first generations, and in a way that the problem of binding is resolved.

c. In order to get rid of the serious dilemma of our age such as fatwa-taqwa, legality-lawfulness or halalness-legality, in presenting the Sunnah, for example, leaving the body-related forms of worship to fiqh books and its spiritual or esoteric dimensions to tasavvufi works; a balanced understanding of form-meaning and surat-spirit of the Anatolian Irfan tradition followed by the sufis from Ahmad Yasavi to Mavlana should be adopted Instead of following a rivayat centered sharh-interpretation with targeeb-tarheeb content.

d. Since presenting the Sunnah to people is essentially an activity of teaching-bringing up, values and virtues such as justice, honesty, human rights and taqwa, which are largely composed of abstract concepts, should be explained with the style of concretization and cosmic grounding taking place among the basic expression styles of the Qur'an and Sunnah.

e. Considering that children's learning takes place through concrete events-facts until the end of adolescence, the Sunnah books for Children should be written based on the style of concretization followed in like Bibel für Kinder/The Bible for Children and a similar book De Koran; Uitleg Voor Kinderen/Annotated Koran for Children written by Abdülvahid van Bommel.

Keywords: Hadith, Sunna, Presenting to the Public, Categorized, to embody

\section{Giriş}

Hz. Peygamber'in örnekliğine ve rehberliğine günümüzde her zamankinden daha fazla ihtiyaç olduğunda şüphe yoktur. Bu örnekliğin bütün verilerinin başta hadisçiler olmak üzere ulema tarafından zapturapt altına alındığı hususunda da herhangi bir tereddüt söz konusu değildir. Bütün mesele genel anlamda sünnet diyebileceğimiz bu örnekliğin günümüze nasıl taşınacağı ve geniş halk kitlelerine nasıl sunulacağı ve davranışlara dönüştürüleceğidir ki hadis-sünnetin halka arzı sorunundan muradımız da budur.

Hemen ifade edelim ki asgari düzeyde de olsa hadis usulü ve tarihi okumamış geniş halk kitlelerinin, hadis kitaplarımızda "Söz, fiil, takrir ve vasıf olarak Nebî̀ye (sav) izafe edilen her şey" șeklinde tarif olunan hadis ve müteradif anlamda kullanılan sünnet ile bu anlayışa göre tarihi süreçte oluşan ilm-i hadis birikiminden doğru bir şekilde yararlanarak Rasûl-i Ekrem'in (sav) örnekliğini öğrenmesi beklenemez. İster hadis kaynaklarının ve şerhlerinin tercümesi ya da yeni şerhler yoluyla olsun isterse va'z-sohbetlerdeki gibi sözel olsun sünnetin ham verileri durumundaki rivayetlerin hadis, rivayet, ravi, sahih, zayıf, mevzu'uydurma gibi tamamen teknik terimler eşliğinde halka arzının da sorunlu olduğunu düşünü- 
yoruz. Konu dil sorunu değildir, çünkü ana dili Arapça olanlar için de durum aynıdır. Ayrıca bunun, halktan bir/bazı şeylerin gizlenmesi ya da her şeyin halka söylenmemesi gibi bir endişeyle de alakası yoktur. Zira hassaten çağımızda herkesin her şeye ulaşma imkânı mevcuttur. Fakat hadis kitaplarının tamamına yakınının tercüme edilmesine, va'z-sohbetler başta olmak üzere din hizmetlerinde çokça hadislere yer verilmesine ve takvim yapraklarından sosyal medya araçlarına kadar hemen her platformun hadislerle bezenmesine karşın adalet, dürüstlük, merhamet ve kul hakkına riayet gibi Hz. Peygamber'in sünnetindeki ayırt edici erdemlerin ve değerlerin bir türlü davranışa dönüş(e)memesi böyle bir sorgulamayı gerekli kılmaktadır. İmam-hatiplikten cezaevi vaizliğine kadar her kademesinde bulunduğumuz otuz yılı aşkın din hizmetleri tecrübemiz de bize hadis-sünnetin halka sunumumuzun hem mahiyet hem de yöntemsel olarak sorunlu olduğunu göstermiştir.

Sünnetin çağa taşınması ya da halka arzının gözden geçirilmesi ihtiyacını en çarpıcı bir şekilde ortaya koyan göstergelerden birisi de Uluslararası Şeffaflık Örgütünün (Transparency Internatıonal-TI) 2017 yılı Yolsuzluk Endeksi (CPI)’ne göre yolsuzluğun en az olduğu ilk yirmi ülkeyi İskandinavya ve kıta Avrupası ülkeler oluştururken, nüfusunun büyük bölümünü Müslümanların oluşturduğu ülkelerin en fazla yolsuzluğun yapıldığı bölgeler şeklinde tespit edilmiş olmasıdır. ${ }^{1}$ Hem maddi olsun manevi olsun bütün hak ihlallerini hem de kamu-özel ayırımı yapmadan her türlü suiistimali kapsayan yolsuzluğun, "Emanet edilmiş olan yetkinin, kamusal ve özel çıkarları zedeleyecek şekilde her türlü kötüye kullanımı" olarak tarif edilmekte oluşu² İslam dünyasının içinde bulunduğu vahameti gözler önüne sermektedir.

\section{Klasik Hadis Çalışmalarından Halkın İstifade Etmesinin İmkan(sızlığ)ı}

Birisi hadis-sünnetin neliği ile birbirleriyle ilişkisi ve diğeri de Sünnetin Müslümanlar için değişmeyen bir karaktere ve davranışlar haline nasıl dönüştürülebileceği olmak üzere hadis ilimlerinin iki temel düzlemde yürüdüğünü söyleyebiliriz. İlki tamamen ulemanın kendi aralarında konuşup tartışacakları bir zemin iken, ikinci düzlemin bir ucunda yine ulema ama diğer tarafında avam ya da halk durmaktadır. Zira İslami ilimlerin diğer dallarında olduğu gibi ilm-i hadisin de nihai hedefinin, dinin temel maksadına muvafık olarak insanların dünyada ve ahirette huzurunu temine yönelik çalışmalar yapmak olduğunda şüphe yoktur. 0 halde temel soru şudur: Ortalama halk yaşamın her alanına dair Rasûlüllah'ın (sav) örnekliğini nereden ve nasıl öğrenecektir? Pekâlâ, ilm-i hadis perspektifinden ba-

1 bk. Funda Buz - Melike Rana Erul, "Sosyoekonomik Gelişmişlik Düzeyinin Yolsuzluk Algı Endeksi Üzerindeki Etkisine İlişkin Bir Analiz”, International Journal of Public Finance 3/2 (2018), 234.

2 M. Hakan Özbaran, "Yolsuzluk ve Bu Alanda Mücadele Eden Uluslararası Örgütler ve Birimler", Sayıștay Dergisi Temmuz-Aralık (2003), 18. 
kıldığında adına ister hadis ve sünnetin aktüel değeri denilsin, ister sünnetin çă̆a yakınlaştırılması ya da taşınması densin ve isterse asrın idrakine sünnetin söyletilmesi veya sunulması densin, okulda öğrencileri, camide cemaati ve cami dışı farklı faaliyetlerde ya da sosyal medya mecralarında halkı Hz. Peygamber'in örnekliğiyle ve rehberliğiyle buluşturmaya çalışan (tıbbi ifadeyle) pratisyenlere başucu veya el kitabı olabilecek çalışmalar mevcut mudur?

İslâmî ilimler tarihi içerisinde devasa bir hacme ulaşan hadis ve sünnete dair literatürün büyük oranda "hadis-sünnetin neliği" ile ilgilendiği ve son bir buçuk asırdır ise 'şimdi'yi de kapsayacak şekilde bir alan evirilmesiyle artık hadis merkezli çalışmaların adeta 'kültür tarihi' perspektifini haiz bir nitelik halini aldığı yönündeki Özafşar'ın tespitini ${ }^{3}$ fevkalade önemli buluyoruz. Bu evirilmenin gelinen noktada gerek hadis ilminin kendisiyle gerekse bu ilmin mütehassıslarıyla ilgili farklı açılımlara zemin oluşturmasına imkân sağlayacağı açıktır. Ne ki Özafşar’ın 'bugünün hadisçisi kimdir?' sorusuna verdiği 'Akademik hadisçi' şeklindeki cevabın ${ }^{4}$ mevcudu nitelediği, lakin en kaba ifadeyle 'sünneti halka sunan kişi' gibi bir vazifeyle de ilişkilendirilmesi gerektiği kanaatindeyiz. Bir taraftan öğrencilerine uzmanlık düzeyinde tıp eğitimi-öğretimi veren ama diğer yandan da poliklinikte/muayenehanesinde halka hekimlik hizmeti veren akademisyen bir tıpçı profilinin hadisçi için de geçerli olması gerektiğini düşünüyoruz. Elbette salt ar-ge ile uğraşanlar da olacaktır. Tabi böyle bir kabul, hadis ilminin alanının veya konusunun da aynı şekilde düşünülmesini gerektirir. Aksi takdirde Rasûl-i Ekrem'in (sav) sünnetinin halka kim tarafından ve nasıl arz edileceği ya da fiiliyata geçirilmesi ve davranışa dönüştürülmesi anlamında sünnetin nasıl aktüel hale getirileceği hususuna cevap aranması icap eder.

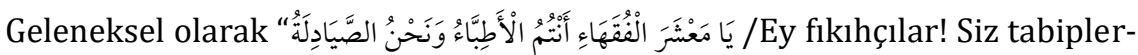
siniz, biz ise eczacılar"5 şeklindeki ilm-i hadis ve hadisçi anlayışının genel olarak ilk dönemlerde hadisten fikhî istinbat işini fıkıhçlara bırakan ama daha sonra ale'lebvâb tarzı telifatla fikhu'l-hadîse de yönelen bir seyir takip ettiği malumdur. İster fıkıh merkezli musannefat içerisinde olsun isterse az sayıdaki müstakil eserlerde olsun fikhî hadisler dışında kalan zühd ve ahlak konulu rivayetlerde de tasnif döneminin temel yaklaşımı olan tespit ön plandadır ki bu alandaki rivayetlerin yorum ve halka arzının da tasavvuf ve ahlakla ilgilenen ulemaya havale edildiğini

${ }^{3}$ Mehmet Emin Özafşar’ın bu hususta kaleme aldığı iki makale başka yazıların da ilavesiyle müstakil bir kitap olarak da yayımlanmıştır. bk. Mehmet Emin Özafşar, “'Hadisin Neliği' Sorunu ve Akademik Hadisçilik", İslâmiyât 3/1 (2000), 33-53; Mehmet Emin Özafşar, "Hadis İlminde Alan Evrilmesi", Íslâmiyât 6/4 (2003), 105-120; Mehmet Emin Özafşar, Hadis ve Kültür Yazıları (Ankara: Otto Yayınları, 2015), 72 vd.

${ }^{4}$ bk. Özafşar, Hadis ve Kültür Yazıları, 25.

5 Ebû Bekr Ahmmed b. 'Alî el-Hुațîb el-Bagdâdî, Nașîhatü ehli'l-ḥadîs, thk. 'Abdülkerîm Ahmed el-Verîkât (Zerkâ: Mektebetu'l-Menâr, 1408), 45 (no. 24); Bu ifade ve muhteva değerlendirmesi için bk. Ataullah Şahyar, “'Ey Fakihler Zümresi! Sizler Tabipsiniz, Bizler ise Eczacıyı!' Sözünün Tespiti ve Muhteva Değerlendirmesi”, Hadis Tetkikleri Dergisi 13/1 (2015), 75-94. 
söylemek hatalı olmaz. Bu tutumun hadis tarihi boyunca sürdürüldügü, Kütüb-i tis'a gibi temel hadis kaynaklarından şerhlere ve rical edebiyatından usûl kitaplarına varıncaya kadar hadis ilimlerinde ortaya konan çalışmaların çok büyük oranda muhatap olarak ulemayı ya da en azından belirli bir dini tahsil yapmış kişileri almasından anlașılmaktadır. Yani hadisçi ve hadis ilimleri maksat ve mevzu olarak bütün kesafetini teoriye ve teknik bilgilere yöneltmiş, ulemanın ihtiyaç duyacağı bilgiyi üretmekle ilgilenmiștir. Nitekim Riyâzu's-sâlihîn tarzı birkaç eser dıșında ortaya konan literatürün tamamına yakınından ancak bu ilmin usulü, tarihi ve ıstılahlarını okuyanlar doğru bir şekilde yararlanabilmektedir. Hatta Nevevî'nin mezkûr eseri de yalnızca seçme bazı rivayetleri yine teknik bir dille sunumdan ibarettir.

Hal böyle olunca Selahattin Polat'ın dediği gibi ulemanın ulemaya aktarması ve uzmanların ıttılalarına sunması gereken bilgilerden oluşan hadis kitaplarının, tercüme edilmek suretiyle dini ilimlerde herhangi bir altyapısı bulunmayan geniş halk kitlelerinin önüne serilmesini doğru bulmadığımızı belirtmek isteriz. ${ }^{6}$ Zira bunların kendine has terminolojileri ve metodolojileri vardır ki bunlar ancak uzmanları tarafından doğru anlaşılabilir. Bu hassasiyet gözetilmediği içindir ki örneğin Sahîh-i Müslim tercümesinden 'üç günden fazla kurban etlerini biriktirmeyin' hadisinin okunup tatbik edilmesinden tutun da sosyal medyada paylaşlan bir hadisin kaynağı olarak el-Mevzûâtu'l-kübrâ veya Keşfu'l-hafâ'nın gösterilmesi gibi garip ve de cahilane davranışlar sergilenebilmektedir. Bu durum salt yabancilar için değil, anadili Arapça olanlar için de geçerlidir. Tıp eğitimi almamış birisinin bazı tıp kitaplarını ve makalelerini okuyarak doktorluğa soyunması durumunda 'sahte doktor' yaftasıyla damgalanması ve ciddi yaptırımlar uygulanması ne kadar yerindeyse aynı duyarlılığın hadis ve diğer dini ilimlerde de gösterilmesi gerekmez mi?

Hadis rivayetinin yapısı gereği hıfz ve kitabet dönemlerinde tespit işi ön planda tutulurken, tasnif devrinden itibaren tespitin yanı sıra hadisler yorumlamaya da tabi tutularak ale'l-ebvâb tarzı eserler oluşturulmuş, hatta İbn Hanbel'in Müsned'i örneğinde görüleceği üzere salt hadisleri derleme maksadıyla telif edilen kitaplar dahi fıkhî zemine çekilmeye çalışılmıştır. Hadisleri anlama ve yorumlama maksadıyla temel hadis kitaplarına yapılan șerh çalışmalarının tamamına yakınında -temel hadis kaynaklarının yapısının da bir gereği olarak- isnad, filolojik tahliller ve fikıh ön planda tutulmuştur. İbn Ebî Cemra'nın (ö. 699/1300) Buhârî̀den seçtiği sınırlı sayıdaki rivayetleri şerh ettiği Behcetü'n-nüfûs'u dışında fikhî içeriği değil de tasavvufî ve ahlâkî yorumu esas alan kapsamlı çalışmalar ise daha ziyade Hakîmü’t-Tirmizî (ö. 320/932), Kelâbâzî (ö. 380/990), Konevî (ö. 673/1274) ve

\footnotetext{
${ }^{6}$ bk. Selahattin Polat tarafından 13.01.2021 tarihinde online olarak sunulan 'Günümüzde Hadise Bakış' başlıklı konferans, https://www.youtube.com/watch?v=hzOqQxGqWAU.
} 
Bursevî (ö. 1137/1725) gibi tasavvufçularca kaleme alınmıştır. ${ }^{7}$

Hadis-sünnetin anlaşılması ve yorumlanması çabaları olarak karşımıza çıkan klasik hadis şerhlerinde de tıpkı aslî hadis kaynakları gibi muhatap kitle alimler olup bunlardan ortalama bir insanın doğru bir şekilde istifadesi imkânsız değilse de oldukça sınırlıdır. Zira genel anlamda isnada ve metne yönelik izahlara dayanan bu şerhler sadece hadislerin aidiyetlerine dair ittisal ve güvenirlik bilgilerini muhtevi olan isnad tetkikleri açısından değil, aynı zamanda metinleri anlamayla alakalı dilsel izahlar ve fikhî hükümlere varıncaya kadar hadislerin yorumları perspektifinden de tamamen teknik eserlerdir. Dolayısıyla genel olarak klasik şerhlerin öne çıkan on beş kadar özellikleri dikkate alındığında bunlardan doğru bir şekilde yararlanmak isteyenlerin önce hadis usulü, tarihi ve literatürü okumaları icap etmektedir. ${ }^{8}$ Yapılan tespitlere bakılırsa geçtiğimiz yüzyılda Hindistan'da ve son yıllara kadar Türkiye'de yazılan șerhlerin de “öncekileri özetlemekten ileri gidemediği” anlaşılmaktadır. ${ }^{9}$ Dolayısıyla ister temel hadis kitapları olsun isterse genel olarak hadis şerhleri olsun hadis ilimleri alanındaki klasik eserlerde muhatabın ulema olduğu gayet açıktır. Bırakın ortalama dindar bir vatandaşı, ilm-i hadisle ilgili ciddi bir okuma yapılmadan mevcut haliyle hadis literatüründen istifade edilmesi durumunda -önyargıdan kaynaklı oryantalist yanılgıları söylemeye bile hacet yok- bilimsel nitelikli çalışmalarda dahi ne tür faciaların oluşabileceğine dair mebzul miktarda örnekler söz konusu olabilmektedir. ${ }^{10}$

\section{Modern Dönem Hadis Çalışmalarından Halkın İstifade Etmesinin İmkan(sızlığ)1}

Yaklaşık son iki asırdır kısaca "hadis/sünnet problemleri" başlığı altına derç edilebilecek çalışmaların hareket noktasını genel olarak tarihten tevarüs edilen râvî, mervî ve rivayet keyfiyeti, metodoloji gibi yapısal olsun yapay olsun ${ }^{11}$ akademik düzeyde ele alınmayı gerektiren nitelikteki sorunlar oluşturduğunu söylemek

7 bk. Zişan Türcan, Hadis Şerh Geleneği Doğușu Gelișimi ve Dönüșümü (Ankara: TDV Yayınları, 2011), 161. Türcan tarafindan hadis şerh geleneğinde dört ana eğilim olduğu tespiti yapılmıș olmakla birlikte Tasavvufî șerhler kısmı dıșındakileri teke irca etmek de mümkündür. Klasik șerhlerin genel özellikleriyle ilgili geniş bilgi için ayrıca Mustafa Işık'ın Klasik İlk Dört Asırda Hadis Şerhçiliği ve Enbiya Yıldırım'ın Geleneksel Hadis Yorumculuğu adlı eserlerine müracaat edilebilir.

8 Klasik şerhlerin genel özellikleri hakkında geniș bilgi için bk. Mehmet Efendioğlu, "Şerh”, Türkiye Diyanet Vakfi İslâm Ansiklopedisi (İstanbul: TDV İslâm Araştırmaları Merkezi, 2010), 38/560.

${ }^{9}$ bk. Türcan, Hadis Şerh Geleneği, 313; Erdinç Ahatll, "Klasik ve Cumhuriyet Dönemi Hadis Şerhçiliği: Şekil ve Muhteva Açısından Bir Mukayese", İslam ve Klasik (İstanbul, 2008), 40; Erdinç Ahatll, "Cumhuriyet Dönemi Türkçe Hadis Șerhlerine Dair Bazı Mülahazalar -Ebû Dâvûd, İbn Mâce ve Dârimî Şerhleri Üzerine Bir Analiz-", Hadis Tetkikleri Dergisi 6/2 (2008), 30.

10 Tercüme, ıstılah ve kaynak okuması gibi durumlardan kaynaklanan hatalı anlama örnekleri için bk. Selçuk Coşkun, Hadise Bütüncül Bakış (İstanbul: İFAV, 2016), 44-94.

${ }^{11}$ Bu problemlerin neler olduğuna dair bir fikir vermesi için bk. Abdulkadir Evgin, "Hadis'e Dayalı Bazı Problemlerin Günümüze Yansımaları”, Dinî Araștırmalar Dergisi 5/13 (2002), 177-186. 
durumundayız. ${ }^{12}$ Hint alt kıtasında başlayıp Mısır ve Anadolu'da devam eden hadis-sünnet merkezli tartışmaların ise yine tespite yönelik metodoloji odaklı olduğunu belirtmeye bile ihtiyaç yoktur. ${ }^{13}$ Son olarak Batı'da dini metinleri anlama ve yorumlama bağlamında ileri sürülen hermeneutik ya da göstergebilimi gibi modern anlama ve yorumlama yöntemlerinde "okuyan ve anlayan" öznenin bizatihi araştırıcının kendisi olması sebebiyle bu tür okuma biçimlerinden hadis-sünnet alanında istifadenin imkanını soruşturan çalışmalar da yine münevverlere hitap etmektedir.

Temel hadis kitapları olsun bunlar üzerine yapılan şerh çalışmaları olsun hadis-sünnet etrafında oluşan literatüre dair yukarıda yansıtılmaya çalışılan fotoğraftaki perspektifin, Sünnet'in halka arzı noktası olduğu bilinmelidir. Bu literatürün ulemaya bakan yönüyle şekil, muhteva ve yöntem olarak değeri bahsi diğerdir. Değerlendirmelerimiz tamamen herhangi bir dini tedrisat görmeyen sevad-ı azamın hayatın farklı alanlarında Rasûl-i Ekrem'in (sav) örnekliğini öğrenip davranışa dönüştürmek istediğinde mevcut hadis edebiyatından bu ihtiyacını giderip gideremeyeceğiyle sinırlı görülmelidir.

Dile getirmeye çalıştığımız ihtiyacın karşılanması noktasında klâsik hadis kaynaklarımızın yetersiz oluşu ve bunların "her isteyenin rahatlıkla yararlanabileceği türden eserler olmadı̆̆ı” tespiti Diyanet İşleri Başkanlığını harekete geçirmiş ve "hadislerin mesajını zamana taşıma ve güncelleme" iradesi ortaya çıkmıştır. Bu irade Türkiye'deki İlahiyat ve İslami ilimler Fakültelerinde görev yapan seksen beş akademisyen hadisçinin birikimleriyle birleşerek Hadislerle İslâm adlı kıymetli çalışmayla neticelenmiştir. Çalışmada neyin nasıl yapılmak istendiği şöyle ifade edilmektedir: "Sevgili Peygamberimiz (sav) tarafından sergilenen örnek tutum ve davranışları, onun (sav) söz ve hadislerindeki mesajları; kısacası onun (sav) çağlar üstü örnekliğini sade ve anlaşılır bir dille günümüz insanına ulaştırmayı amaçlayan, özelde Anadolu insanının genelde İslâm toplumunun modern zamanlardaki problem ve ihtiyaçlarını dikkate alan, hedef kitle olarak ortalama okuyucuya hitap ettiği için teknik olarak hadis ilminin sorunlarını okuyucuya açmayan, ülkemizdeki hadis uzmanlarının birikimlerinden yararlanan, seksen beş yazarın katkı sunduğu

12 Mehmet Said Hatipoğlu'nun öncülük ettiği ve hadis kaynaklarının tenkit esaslı okunmasına dayanan, müstakil bir metodoloji önermekten ziyade bazı metodik sorunlara ve çözüm yollarına dikkati çeken Enbiya Yıldırım'ın “Hadis Problemleri” ve Yavuz Ünal'ın "Hadislerin Tespitinde Yöntem Sorunu” gibi akademik çalışmaları kastediyoruz.

13 Geniş malumat için konuyla ilgili düzenlenen sempozyum bildiri ve müzakerelerine bakılabilir. Mesela bk. Erdinç Ahatlı, "Hadis İlminde Metodoloji Problemleri”, İslâmî Ílimlerde Metodoloji/Usûl Mes'elesi II (İstanbul: Ensar Neşriyat, 2005), 801-814. Ahatl bu bildirisinde metodoloji arayışlarındaki temel saiklere dikkati çektikten sonra Türkiye'de akademik anlamda somut bir şekilde ilk alternatif bir hadis metodoloji ortaya koyan M. Hayri Kırbaşoğlu'nun çalışmasını değerlendirmiştir. Daha sonra ise Mehmet Görmez'in “Sünnet ve Hadisin Anlaşılması ve Yorumlanmasında Metodoloji Sorunu” isimli çalışması ve Mehmet Apaydın'ın "Hadislerin Tespitinde Bütünsel Yaklaşım" adlı tezi gibi önemli gayretler sergilenmiştir. 
katılımcı bir çabanın ürünüdür."14

Evvela son derece yerinde bir tespitle ve hedefle yola çıkma iradesini gösterip neticelendirenlere ve de böylesi büyük bir projeye gerek makaleleriyle gerekse editörlük hizmetleriyle destek verenlere şükranlarımızı sunmak hakşinaslığın icabı olsa gerektir. Siyasi, bürokratik, konjonktürel, sivil ve resmi diğer şartların sınırlılıkları da nazar-ı dikkate alındığında DİB'nın yedi cilt tutarında böylesi külliyatlı bir eseri okuyucuyla buluşturabilmesi fevkalade değerlidir.

İslam ve hayatı bütün yönleriyle sekiz ana bölüm altında 330 civarında konu başlığı halinde ele almaya gayret eden ilk konulu hadis şerhinin Hadislerle İslam çalışması olduğunu söylemek yanlış olmaz. Konulu olması yanında her konuda yaklaşık otuz hadisten istifadeyle toplamda tekrarsız on bin rivayete atıfta bulunulması suretiyle ve bütüncül bir bakış açısıyla hadislerin hadislerle yorumu yönteminin benimsenmesi de evaildendir. Ayrıca böyle bir çalışmaya olan ihtiyacı bütün açıklığıyla ortaya koyan, eserin amacını ve yöntemini detaylıca izah eden ve hadis-sünnete dair ilk elden bilinmesi gereken malumatı vermeye çalışan yüz sayfayı aşkın mukaddimenin de çok kıymetli olduğu kanaatindeyiz. Hâsılı kelam $H a-$ dislerle Íslam'ı özgün, kolektif ve konulu ilk çağdaş hadis şerhi olarak değerlendirmek yerinde olacaktır. ${ }^{15}$ Henüz ikincisi de telif edilebilmiş değildir. İlk baskısının üzerinden yedi-sekiz yıl geçmesine ve dört-beş baskısı yapılıp farklı dillere çevrilmiş olmasına rağmen bu esere yazılmış makale veya kitap düzeyinde bilimsel bir değerlendirmenin varlı̆̆ından haberdar değiliz.

Bu makalenin yazımı esnasında hatta bitmek üzereyken konuyla ilgili iki yeni kitaba muttali olduk. Sünnet ve Sünnetin Günümüze Taşınması adlı üç bölümden oluşan çalışmasında Recep Aslan ilk iki bölümde sünnetin neliği üzerinde durmuş ve son bölümde günümüze taşınmasında itibara alınması gereken bazı ilkeleri ön plana çıkartmıştır. ${ }^{16}$ Diğer çalışma ise Hayri Kırbaşoğlu'nun Sünneti Çağa Taşımak adlı kitabı olup yayımlanınca büyük bir heyecanla derhal temin edip dikkatlice okuduk. Sayın Kırbaşoğlu'nun bu çalışması, üç aşamalı bir projenin üçüncü basamağını teşkil etmektedir. Önce eleştirel bir yaklaşımla İslam Düşüncesinde Sünnet adlı eseriyle mevcudun yetersizliğini ve yeni bir metodolojiye olan ihtiyacı dile getirmiş, arkasından klasik usullerden de istifadeyle Alternatif Hadis Metodolojisi çalışmasını yapmış ve projesinin üçüncü basamağında ise ilk iki çalışmayla temel-

14 bk. Hadislerle İslam (Ankara: Diyanet İșleri Başkanlığı, 2017), 1/41-42.

15 Eserin amacı ve yöntemiyle ilgili geniş bilgi için bk. Hadislerle İslam, 1/44, 45, 144.

16 Recep Aslan, Sünnet ve Sünnetin Günümüze Tașınması (İstanbul: Ensar Neșriyat, 2020). İlk iki bölüm makalemizle doğrudan alakalı olmadığından yalnızca üçüncü bölümde dikkatlere sunulan ilkeleri arz etmek faydalı olacaktır. Sünnetin günümüze taşınmasında Aslan'a göre şu ilkeler gözetilmelidir: Hadisler Kur'an ayetleriyle birlikte ele alınmalı, rivayetler bütünlük içerisinde işlenmeli, geleneksel hadis ilimlerinden istifade edilmeli, sünnetten kastedilen mana-amaç-ilke ve hikmetler tespit edilmeli, Hz. Peygamber'in üslubu ve anlatım tarzı bilinmeli, Hz. Peygamber'in örnekliği çağımıza taşınmalı, sünnetin bağlayıcılık yönü iyi anlaşılmalı, yerellik ve evrensellik yönleri ayırt edilmelidir. 
lerini attığı düşünceleri doğrultusunda Sünneti ve Hadisi Anlama ve Yorumlamada Yöntem önerisini deklare ederek ilim adamlarının ıttılalarına sunmuş olmaktadır. Dolayısıyla ilk iki adımda hadisin ve sünnetin sübutunu, son çalışmasında ise delâleti problemini ele almakta17 ve "Nebevî paradigmanın 21. yüzyılda yaşanabilir ve sürdürülebilir bir yorumunu yapmak için göz önünde bulundurulması gereken yöntemsel esasları"nı belirlemeye çalışmaktadır. ${ }^{18}$ Belirlediği esaslar muvacehesinde yazılmasını önerdiği çağdaş bir șerhte bulunmasını düşündüğü on altı bölümü ve alt başlıklarını da çalışmanın sonunda dikkatlere sunmaktadır. ${ }^{19}$ Çağımızın ihtiyaçlarının küresel ölçekte ve sünnetin de bu ihtiyaçları karşılamada bütün insanlığa ilham kaynağı olabilecek şekilde ele alınması yönüyle dikkat çeken bu projenin de tıpkı Hadislerle İslam gibi varlık bulmasının Sünnet'in çağımıza taşınmasına büyük katkı sağlayacağında şüphe yoktur.

Kırbaşoğlu bahis konusu çalışmasında şimdiye kadar çağdaş bir hadissünnet şerhi yapılamadığını ve çağdaş bir konulu şerhe mutlak ihtiyaç duyulduğunu vurguladıktan sonra Hadislerle İslam'a dair sekiz sayfalık bir eleștiri yapmıștır. Bu tenkidini, Hadislerle Íslam'ın "çağdaş bir şerh denemesi olmaktan hayli uzak" şeklindeki kendi ifadesiyle özetlemek mümkündür. Başarılı bulduğu tek bölüm ise Tıbb-ı Nebevĩ dir. ${ }^{20}$

Kur'an dışında hiçbir kitabın hatadan ve eksiklikten azade olamayacağında şüphe yoktur. Nitekim Kırbaşoğlu da bazı örnekler eşliğinde yedi madde halinde Hadislerle Íslam'ı tenkide tabi tutmuştur. Alanında ilk olması ile siyasî ve sosyal realiteyi dikkate alma gibi bir sorumluluğu ve zorunluluğu bulunan DİB'in himayesinde vücut bulmasının, Hadislerle Íslam'ın gelişime açık yönlerini etkileyen en önemli faktörler olduğu söylenebilir ki Kırbaşoğlu'nun tenkidinin nirengi noktasını da bu durum oluşturmaktadır. Söz konusu eleştiriler içerisinde bizim de katıldığımız hususlar bulunmakla birlikte böylesine büyük bir emeğin ve mesainin toptancı bir yaklaşımla ve bazı katalog-sloganik cümlelerle değersizleştirilmeye çalışılmasını ve 'ortada ciddiye alınabilecek gerçekten çağdaş bir şerhten ziyade halka ve genel okuyucu seviyesini bile tutturamayan bir vaaz edebiyatıyla karşı karşıyayız' denilerek tahkir edilmesini hakkaniyetle bağdaştıramadığımızı ifade etmek isteriz. 'Sünneti bireysel davranış ve ahlaka-adaba indirgeyen, sünneti karikatürize edip değersizleştiren, kurbağaları ürkütecek rivayetlere ve yorumlara yer vermeyen, yöneticilerin yolsuzluklarından bahsetmediği için kayırmacı, yazarları Nebevî sün-

17 bk. M. Hayri Kırbaşoğlu, Sünneti Çağa Tașımak -Sünneti ve Hadisi Anlama ve Yorumlamada Yüntem(Ankara: Ankara Okulu, 2021), 14-15.

18 Kırbaşoğlu, Sünneti Çağa Taşımak, 48.

${ }^{19}$ Projenin bölüm ve alt başlıkları için bk. Kırbaşoğlu, Sünneti Çağa Taşımak, 317-326. Projenin gelişime açık olduğu belirtilerek katkı beklentisine șimdilik, talep edilmesi halinde alt bașlıklarına da katkı sunabileceğimiz "Hıfzıssıhha" bölümünü önermekle iktifa ediyoruz.

20 bk. Kırbaşoğlu, Sünneti Çağa Taşımak, 36-44. 
net konusunda entelektüel çoraklık ve fakirlik illetiyle malul ve de ihbarî cümlelerin inşaî anlama gelebileceğini anlama derinliğinden oldukça uzak ve mahrum olan, emekçileri sermayenin ve patronların insafına ve vicdanına havale ederek farkında olmadan Hz. Peygamber modelinin değil de sermayenin safında yer tutan' şeklindeki itham edici ve maksadı aşan yargıların bilimsel eleştiri dahilinde görülmesi gayr-i kabildir. Hadislerle İslam'a dair bahis konusu değerlendirmede yer alan “...saltanat, despotizm ve totaliter rejimler ya da itaat kültürü gibi hayati önemi haiz kavramlara da taramalarda rastlanamamış olması aslında yapılan şerhin neye hizmet ettiği konusunda bizlere epey ipuçları vermektedir' şeklindeki cümle, eleştirinin bazı ilmi tenkit örneklerini de içinde barındıran siyasi bir eleştiri olduğunun ipuçlarını vermektedir. Şüphesiz yöntemi, üslubu ve muhtevası gibi perspektiflerden Hadislerle Íslam adlı eserin lehinde ve aleyhinde pek çok bilimsel değerlendirmeler yapılabilir ve yapılmalıdır. Nitekim makalemizi ilgilendiren yönü itibariyle bizim de mezkûr esere ilişkin birtakım mülahazalarımız söz konusudur.

Yazar veya başka bir sıfatla oluşum süreçlerinde herhangi bir görev almadığımız Hadislerle İslam'ı, birisi İlahiyat/İslami İlimler öğrencilerinden ve diğeri de çoğunluğu tabip ve ilahiyat harici yüksek tahsil yapmış iş adamlarından oluşan ama aralarında yüksek tahsili olmayanların da bulunduğu mahalle komşularımızdan oluşan yaklaşık on beşer kişilik iki ayrı grupla birlikte okuma imkânı bulduk. Covid-19 salgını öncesi vicahen icra ettiğimiz bu okumalarda muhataplarımızın ellerinde çoğunlukla serlevha hadisler cildi mevcut iken bir kısmı da eserin tamamından matbu-dijital olarak takip ettiler, bendeniz de eserdeki her konuyu bazen önemli yerlerini okuyarak ama çoğunlukla özetleyerek dersleri gerçekleştirdik. Dini yüksek tahsil yapmakta olan gençlik grubunda eserin baştan sona kadar takriri tamamlanmış, diğer toplulukta ise yarıya gelinmiştir. Bu iki okumamız neticesinde Hadislerle Íslam'ın, girişinde hedef kitle olarak ortalama okuyucunun seçildiği ve teknik olarak hadis ilminin sorunlarının okuyucuya açılmadığı ifade edilmesine rağmen 'ortalama okurlar' için uygun olmadığı ama dini yüksek tahsil yapan grup için faydalı olduğu kanaati hasıl olmuştur. Dolayısıyla bu eseri de tıpkı klasik şerhler gibi daha ziyade hadis ilimleriyle iştigal edenlerin istifade edebileceği bir çalışma olarak değerlendiriyoruz.

Doğa bilimleri de dahil olmak üzere her ilmin, birisi yalnızca mütehassıslarının ilgileneceği ve belirli bir alt yapısı olanların anlayabileceği ve diğeri de o ilmin halka/öğrencilere yönelik yönü olmak üzere iki veçhesinin bulunduğu yadsınamaz. $O$ halde hadis ve sünnet konusunda da bu iki veçhe birlikte düşünülmelidir. Bunlardan ilki Kırbaşoğlu'nun ifadesiyle "Yaşanabilir ve sürdürülebilir bir Nebevî paradigmayı inşa edebilmek için bir anlama ve yorumlama yöntemi geliştirmek" 21 ki bu, örgün eğitimdeki öğretim programları ve müfredatları mesabesindedir ve

21 bk. Kırbaşoğlu, Sünneti Çağa Taşımak, 27. 
geliştiricileri de okurları da akademik-entelektüel çevreler yani ulemadır. Sünneti çağımıza taşımada ya da Nebevî paradigmayı asrın idrakine sunmada ne ölçüde başarılı olduğu tartışmalarından sarf-ı nazar ederek Hadislerle İslam adlı çalışmayı da bu kategoride değerlendiriyoruz. Diğeri ise öğretim programlarında yer alan soyut hedefleri somut hale getirmek suretiyle öğretimi doğrudan yönlendiren ve öğretmenin bulunmadığı durumlarda onun görevini yerine getiren ders kitapları gibi doğrudan ortalama okurları muhatap alan çalışmalardır. Fıkıh ilminde bu ayırımın yapıldığını ve halkın fıkha dair bilgileri okuyabileceği ilm-i hâller hazırlandığını söyleyebiliriz. Benzer bir ayırımın hadis ilimlerinde de yapılabileceğini düşünüyoruz.

\section{Sünnet’in Halka Arzı Sorununa Yönelik Bazı Çözüm Önerileri}

Sünnetin halka arz edilmesi sorunsalına toplum perspektifinden bakıldığında en az ibadet-i mersûmelerin îfâ edil(e)memesi kadar bu formel ibâdâtta hedeflenen adalet, dürüstlük ve kul hakkına riayet etmek gibi ahlakî davranışlar kıtlı̆̆lnın da önemli olduğu ortadadır. Zira ahlaki değerlerin Müslümanlar tarafından bireysel ve toplumsal hayata taşınması diyebileceğimiz dindarlığın günümüzde giderek etkisinin ve canlılığının pörsüdüğü bir vakıadır. ${ }^{22}$ Son dönemlerde yapılan bazı araştırmalarda bir taraftan Avrupa'nın en dindar ülkesi olarak Türkiye görünürken, ${ }^{23}$ diğer taraftan ise düzenli olarak beș vakit namaz kılanların oranının ancak \%40 civarında olduğu anlaşılmaktadır. ${ }^{24}$ Fakat daha önce de değinildiği gibi asıl çarpıcı olan, CPI'nin 2017 yılı yolsuzluk endeksi verilerinde İslam ülkelerinin yolsuzluğun en az olduğu ilk yirmi ülke arasında yer al(a)mamasıdır. ${ }^{25}$ Bu sonuçların oluşmasında mesela namazın farz ve yolsuzluğun/hırsızlığın da haram olduğunun bilinmemesi olduğunu varsaymak kabil değildir. ${ }^{26}$ Bütün mesele, insanların kahir ekseriyeti tarafından namaz ve oruç gibi formel ibadetlerin nihaî hedefinin haksızlık, adaletsizlik, kul hakkı yemek, aldatmak, yalan söylemek ve rüşvet alıpvermek gibi kötülüklerden arınmak olduğu bilindiği halde bu bilgiyi davranış hali-

22 bk. Mehmet Görmez, “Din ve Dindarlık”, Diyanet Aylık Dergi 265 (Ocak 2013), 01; Şemsettin Kırıș, "Yeni Sünnet Tanımları Bağlamında Sünnet-Dindarlık İlişkisi Üzerine Bazı Mülâhazalar”, Hadis Tetkikleri Dergisi 15/2 (2017), 15-35.

23

bk.

https://www.indyturk.com/node/219286/d\%C3\%BCnya/pewara\%C5\%9Ft\%C4\%B1rmas\%C4\%B1 . Bu araştırmaya göre halkın yüzde 89'u hayatında dini önemli görüyor.

24 bk. https://tr.sputniknews.com/analiz/201905151039059892-optimardan-din-inanc-anketi-yuzde39-duzenli-namaz-kiliyor-oruc-tutanlarin-orani-yuzde-66/.

25 bk. Buz - Erul, "Sosyoekonomik Gelişmişlik Düzeyinin Yolsuzluk Algı Endeksi Üzerindeki Etkisine İlişkin Bir Analiz", 234.

26 Nitekim kaçak elektrik kullanımıyla ilgili İHL ve genel lise öğrencileri üzerinde yapılan bir araştırmada katılımcıların \%84'nün büyük günah olarak gördüğü, kaçak kullanıma karar vermede 'dinime göre karar veririm' diyenlerin \%37'de kaldığı ve bu cevaplarda din eğitimi alanlaralmayanlar (İHL-GL) arasında anlamlı bir farkın bulunmadığı sonucuna varılmıștır. bk. Yusuf Macit, "Kaçak Elektrik Olgusu: Dini, Ekonomik ve Psiko-Sosyal Açıdan Yaklaşım”, Süleyman Demirel Üniversitesi İlahiyat Fakültesi Dergisi 32 (2014), 115-118. 
ne dönüştürmede başarısız olunmasıdır. Dolayısıyla bir taraftan çağımızda geniş kitlelere sunulacak olan Sünnet'in niteliği üzerinde kafa yorulurken, diğer yandan da etkili sunum yöntemleri ve yollarına yoğunlaşmak gerekmektedir.

Hadis-sünnetin halka arzına yönelik çalışmalarda dikkate alınması gerektiğine inandığımız temel esaslara dair bazı mülahazalarımızı arz etmek istiyoruz.

\subsection{Hadis-Sünnet Ayırımı ve Hadislerden Ziyade Sünnetin Arz Edilmesi}

Hadisi "Söz, fiil, takrir ve vasıf olarak Nebî’ye (sav) izafe edilen her şey" şeklinde tarif edip sünneti de hadis ile müteradif anlamda kullanan ehl-i hadisin anlayışı ${ }^{27}$ yerine, bu iki kavramın birbirlerinden farklı tarif edilmesi gerektiği hususunda son dönem hadisçileri arasında görece bir konsensüs sağlanmış görünmektedir. ${ }^{28}$ Günümüzde sünneti, Kur'ân'ın uygulanışını ve sîratü'n-Nebî'yi de içine alacak şekilde kısaca Hz. Peygamber'in dini yaşam tarzı ve ortaya koyduğu yolun adı şeklinde; hadisi de bu sünneti sonraki nesillere aktaran her bir rivâyet şeklinde anlayarak modern dönemlerde hadis-sünnet ayırımın temellerini atan Mûsâ Cârullah Bigiyef'in (ö. 1949) bu yaklaşımı ${ }^{29}$ kabul görmekte ve belirli bir tarife dönüştürülmeye çalışılmaktadır. Kırbaşoğlu tarafından yapılan ${ }^{30}$ ve Hadislerle Íslam'da da benimsenen "Medine toplumu ve devleti içinde Hz. Muhammed'e (sav) sosyal, siyasal, ekonomik ve ahlaki tüm sahalarda rehberlik eden esaslar" 31 șeklindeki sünnet tarifinde kısaca Allah Rasûlü'nün (sav) örnekliği ve rehberliği vurgulanarak onun dünya görüşünün ya da hayat tarzının sünnet olarak anlaşılması gerektiği ifade edilmiş olmaktadır. Son dönemlerde pek çok araştırmacı tarafından girişilen farklı sünnet tarifi teșebbüslerinde ortak nokta; sünnet ile hadisin müteradif olmadığı, Hz. Peygamber'in örnekliğinin ve rehberliğinin sünnet, bu sünnetin sonraki

27 bk. Hayrettin Karaman, Hadis Usulü (İstanbul: Ensar, 2014), 16; İsmail Lutfi Çakan, Hadis Usulü (İstanbul: İFAV, ts.), 26; Mücteba Uğur, Ansiklopedik Hadis Terimleri Sözlüğü (Ankara: Türkiye Diyanet Vakfı, 1992), 367; Ahmed Talat Koçyiğit, Hadis Istılahları (Ankara: İlahiyat Yayınları, 1985), 401; Suphi Salih, Hadis İlimleri ve Hadis Istılahları, çev. Yaşar Kandemir (İstanbul: İFAV, 1996), 3; Ahmet Yücel, Hadis Usulü (İstanbul: İFAV, 2018), 45; Muhammed el-Acâc, es-Sünne kable't-tedvîn (Kahire, 1971), 15; Muhammed Ebû Zehv, el-Hadîs ve'l-muhaddiŝnn (Beyrut, 1984), 9; Bünyamin Erul, Sünnet Kavramı ve Sekaleyn Rivayetleri (Ankara: İlahiyat Yayınları, 2007), 13-49; Murtaza Bedir, "Sünnet", Türkiye Diyanet Vakfı İslâm Ansiklopedisi (İstanbul: TDV Yayınları, 2010), 38/150.

28 Modern dönemlerde yapılan farklı sünnet tanımlarını bir arada görmek için bk. Kırıș, "Yeni Sünnet Tanımları Bağlamında Sünnet-Dindarlık İlișkisi Üzerine Bazı Mülâhazalar", 13-15.

${ }^{29}$ bk. İbrahim Hatiboğlu, "Hadis ve Sünnet Terimlerine Farklı Bir Yaklaşım: Fazlurrahman'ın Hadis ve Sünnet Ayırımı", Marife 1/1 (2001), 34.

30 M. Hayri Kırbaşoğlu, Íslam Düşüncesinde Sünnet (Ankara: Ankara Okulu Yayınları, 1996), 104. Kırbaşoğlu'nun bu tarifine katılmakla birlikte uzun bulduğumuzu ve bu haliyle bir tariften ziyade şerhe benzediğini, dolayısıyla daha özlü bir forma sokulması gerektiğini belirtmek isteriz.

31 Hadislerle Íslam, 129. Tarif tırnak içerisinde verilerek alıntı olduğuna işaret edilmesine rağmen Kırbaşoğlu'nun referans gösterilmemesi haklı olarak Hayri hocanın (Sünneti Çağa Taşımak, 21) sitemlerine maruz kalmıştır. 
nesillere taşıyıcısının da hadisler olduğudur. ${ }^{32}$

Genel olarak sahabenin ve hicri ilk üç asırda ehl-i re'y ile ehl-i amel ekollerinin de bu ayırıma kail olduğu ve İmam Şâfiî ile birlikte hadisi merfuya indirgeyen ve sünnet ile eşitleyen ashab-ı hadisin anlayışının ön plana çıktığı tespiti ${ }^{33}$ dikkate alındığında hadis-sünnet ayırımının nevzuhur bir durum olmadı̆̆ı, ihtiyaçları karşılamada ve sorunları çözmede kadim ulemanın ortaya koyduğu farklı yaklaşımlardan birisini tercih ederek geliştirmekten başka bir anlam taşımadığı kabul edilmelidir. Modern dönemlerdeki hadis-sünnet ayırımının gelenekte var olan ayırım düşüncesine değil de oryantalistlere dayandığı ve böyle bir ayırımın muhtemel sakıncaları bulunduğu fikrine katılmadığımızı belirtmek isteriz. ${ }^{34}$

Nebî̀ye (sav) izafe edilen her türlü sözlerin, fiillerin ve onayların yanı sıra nübüvvet öncesi ve sonrası Hz. Peygamber'in sîreti ile hulkî ve halkî vasıflarını, hatta sahabe ve tabiin sözlerini ve uygulamalarını da içine alan hadisler ${ }^{35}$ şüphesiz sünnetin tespitini ve naklini sağlayan en önemli rivayet malzemeleridir. ${ }^{36}$ Hadis külliyatını Müslümanların temel arşiv mirası olarak görüp dindarlığın sürdürülebilirliği bağlamında toplumsal hafızayı 'es-Sünne'ye göre devamlı taze tutmanın tedarikçisi saymak gerekir. ${ }^{37}$ Tabiri caizse hadis rivayetleri, sünnetin veri tabanı ve ham bilgi deposu mesabesinde olup bunlardan yararlanabilmek uzman olmayı gerektirir. Dolayısıyla hadisin tarihini, terminolojisini ve literatürünü bilmeyenlerin bu rivayet verilerini doğru kullanma imkanları yoktur. Mesele sadece hadislerin sıhhat durumları değildir. Zira nice sahih hadisler vardır ki mamulün bih değildir ${ }^{38}$ ve

$32 \mathrm{Bu}$ teşebbüsler ve değerlendirmeler için bk. Yavuz Köktaş, "Bazı Yeni Sünnet Tanımları Üzerine”, Dîvân İlmî Araştırmalar 7/12 (Ocak 2002), 95-160; Ahmet Keleş, Sünnet -Yeni Bir Usul Denemesi(İstanbul: İnsan Yayınları, 2015), 132-145.

33 bk. Bünyamin Erul, Sahabenin Sünnet Anlayışı (Ankara: TDV, 1999), 195, 196.; M. Hayri Kırbaşoğlu, İslam Düşüncesinde Hadis Metodolojisi (Ankara: Ankara Okulu, 2000), 26, 35-37.; Yücel, Hadis Usulü, 40-45; Mehmet Emin Özafșar, Hadisi Yeniden Düșünmek (Ankara: Ankara Okulu, 1998), 81; Mehmet Özşenel, İlk Dönem Hadis-Rey Tartışmaları Şeybânî Örneği (İstanbul: İFAV, 2017), 36-39; Muammer Bayraktutar, "İmam Şâfî̂’nin Hadisleri Anlama ve Yorumlama Yöntemi”, Gelenekselci ve Modernist Paradigmalar Kıskacında İmam Şâfiî, ed. Mahfuz Söylemez (Ankara: Araştırma Yayınları, 2014), 109. 138; Arif Ulu, Tâbiûnun Sünnet Anlayışı (İstanbul: İFAV, 2015), 161-163.

34 bk. Hatiboğlu, “Hadis ve Sünnet Terimlerine Farklı Bir Yaklaşım: Fazlurrahman'ın Hadis ve Sünnet Ayırımı", 44-47.

35 Hadisin tarifi için bk. Nûruddîn 'Itr, Menhecu'n-naḳd fî 'ulî̀l-hadîs (Dimeşk: Dâru'l-Fikr, 1981), 27.

36 bk. Özşenel, Hadis-Rey Tartışmaları, 36; Muhammed Yusuf Guraya, Sünnetin Neliği Sorununa Metodik Bir Yaklaşım -Mâlik'in Muvatta Örneğinde-, çev. Mehmet Emin Özafşar (Ankara: Ankara Okulu, 1999), 137.

37 Kırıș, "Yeni Sünnet Tanımları Bağlamında Sünnet-Dindarlık İlişkisi Üzerine Bazı Mülâhazalar”, 38.

38 Neshe konu olmadıkları halde 25 kadar sahih hadisin hiçbir fakih tarafından hüccet alınmadığını Allûş tespit etmiștir. bk. Ebû 'Abdillâh 'Abdusselâm Muhammed 'Ömer 'Allûș, el-İntihâ' li ma'rifeti'lehâdîs elletî lem yefti bihâ'l-fukahâ ve münâkașetühâ 'alâ żav'i'l-ușûliyyîn ușûli'l-fiḳh ve ușûli'l-hadîs (Beyrut: Dâru İbn Ḥazm, 1996); Her ne kadar Allûş, Sahîhaynda bu nitelikli hadis olmadığını ileri sürse de bizim tespitlerimize göre bu iki eserde de söz konudur. bk. Yusuf Acar, "Fukahanın Amel Etmediği Bazı Sahîhayn Hadisleri ve Buhârî ile Müslim'in Bunlara Yaklaşım Farkı/Some Șahīhāyn Hadiths That the Fuḳahā' Have not Put into Practice and the Difference Between Buknhārī and 
yine zayıf oldukları halde nice hadislerle de amel edilmiştir. ${ }^{39}$ Rivayetlerin delaletlerini doğru anlayabilmek ise çok daha derinlik gerektiren bir husustur. Bütün tarikleri görülmeden, dilsel özelliklerine ve bağlam bilgisine vakıf olunmadan, sünnet ve nihayet Kur'an ile ilişkisi kurulmadan yani bütüncül bakış sağlanmadan bir hadisin doğru anlașılması mümkün değildir. ${ }^{40}$

Diğer taraftan çağa yaklaştırmak, çağa taşımak, aktüel hale getirmek ya da asrın idrakine sunmak/söyletmek kavramları ile hadisler nasıl bir araya getirilecektir? Çünkü hadisler Nebevî yaşamın ve rehberliğin tahkiyesi ve haber vericisi olan sabit tarihî bilgiler olup çağa taşınmaları veya güncellenmeleri ancak dil tasarrufuyla sınırlı olur. Örneğin “İman, yetmiş küsur şubeye ayrılır. En üst derecesi lâilâhe illallah sözü, en alt derecesi ise yolda insanlara eziyet veren bir şeyi alıp kenara koymaktır. Hayâ da imandan bir şubedir." 41 hadisi nasıl aktüel hale getirilecektir? Oysa aynı konudaki diğer hadisler ve ayetler birlikte değerlendirilerek tespit edilecek olan sünneti günümüze taşımak mümkündür. Nitekim merhum Koçkuzu hocamız lisans derslerinde şöyle demişti: "Bu hadisi okuyan veya duyan hacı emmi, yatsı namazından gelirken yolda çocukların top oynamak için kurduğu mini kale tașlarını ayağıyla yolun dıșına itekleyerek sünnete uyduğunu sanır. Halbuki aynı hacı dükkânın önündeki kaldırımı işgal ederek mallarını sokağa yaymış veya trafiği engelleyecek şekilde aracını park etmiş, iște asıl sünnet o malların veya aracın kaldırılıp atılmasıdır." Dolayısıyla çağa yaklaştırılacak ve günümüze taşınacak olan sünnetler olmalıdır, hadisler değil. Sünnetin doğru anlaşılması ve çağa taşınması için böyle bir ayırımın yapılması zorunlu görünmektedir. ${ }^{42}$

Bir başka esaslı soru/sorun da şudur: Hadislerle İslam olur mu? Hadislerden din öğrenilebilir mi? Böyle bir adlandırmayla söylemde de olsa 'Âyetlerle İslam' anlayışına yol verilmiş olmaz mı? Hemen söyleyelim ki kanaatimizce Hadislerle

Muslim's Approach to Them", Hadith 4, (Temmuz 2020), 10-50.

39 bk. Yusuf Acar, “Zayıf Hadisin Amel Karinesiyle Desteklenmesi ve Tirmizînin Süneni”, Necmettin Erbakan Üniversitesi İlahiyat Fakültesi Dergisi [Selçuk Üniversitesi İlahiyat Fakültesi Dergisi 37 (2014), 41-69; Sıhhat-amel ilişkisine dair geniş bilgi için bk. Bekir Özüdoğru, Rivayetlerin Hz. Peygamber'e Aidiyetini Tespitte Amel Olgusu (Samsun: Ondokuz Mayıs Üniversitesi, Sosyal Bilimler Enstitüsü, Doktora Tezi, 2018).

40 "Recm âyeti" hadisi örneğinde bir rivayetin bütüncül yaklaşımla nasıl ele alınabileceğine dair Selçuk Coşkun'un Hadise Bütüncül Bakış adlı çalışmasına bakılabilir.

41 Ebû 'Abdillâh Muhammed b. 'İsmâîl b. İbrâhîm el-Cu'fî el-Buhârî, el-Câmi'u'l-müsnedü'ș-șahîhu'lmuhtașar min umûri Rasûlillâhi șallallâhü 'aleyhi ve sellem ve sünenihî ve eyyâmih, thk. Muhammed Züheyr b. Nâșır (Beyrut: Dâru Tavkı'n-Necât, 1422), “İman”, 2; Ebu'l-Huseyn Müslim b. el-Haccâc b. Müslim el-Ḳuşeyrî Müslim, el-Müsnedü'ș-șahîhu'l-muhtasar mine's-sünen bi nakli'l-adli ani'l-adl an Rasûlillâh șallallâhü 'aleyhi ve sellem, thk. Muhammed Fuad Abdülbâkî (Beyrut: Dâru İhyâi't-Turâsi'lArabî, t.s), "İman", 57-59.

42 Nitekim bir hadis örneğinde konuyu elen bir makalede de söz konusu ayırıma dikkat çekilmektedir. bk. Nurullah Agitoğlu, "Sünnetin Doğru Anlaşılması ve Günümüze Taşınması -'Allah Güzeldir, Güzelliği Sever' Rivâyeti Üzerine Bir Değerlendirme”, İlahiyat Akademi Dergisi: Altı Aylık Uluslararası Akademik Araştırma Dergisi 7-8 (2018), 346. Makalede çağa taşınacak olan sünnetin neliği üzerinde durulmaktadir. 
Islam doğru bir ifade değildir ve ne hadislerden ne de ayetlerden avamın din öğrenme imkânı söz konusu olabilir. Öğrenilmeye kalkışıldığında ise modern selefilerin ya da Seyyid Ahmed Han'ın çizgisine düşülmesi kuvvetle muhtemeldir. İslami ilimlerin birbirlerini tamamlayan bir bütün olduğunu kabul edip bașta namaz ve oruç olmak üzere formel ibadetler ile şeriatın diğer zahiri hükümlerinin fıkıh ve ilmihal kitaplarından öğrenilmesi gerektiği kanaatindeyiz. ${ }^{43}$ Formel ibadetlerin ve hükümlerin nihaî maksadının Müslümanda informel bir ibadet karakteri oluşturmak veya insanı kemal derecesine ulaştırmak olduğu nazar-ı dikkate alınırsa ${ }^{44}$ merhum Ali Yardım'ın sünnet ile ahlâk terimlerinin "Hz. Peygamber'in, bütün hayatı boyunca yapmaya devam ettiği ve pek zorlu bir mâni çımmadıkça terk etmediği hareketlerdir" şeklinde aynı manada kullanıldığını söylemesi oldukça anlamlı durmaktadır. ${ }^{45}$ İşte hadis ve sünnet halka arz edilirken ibadetlerin ve diğer hükümlerin bedene taalluk eden suretleri fikha ve ilmihale havale edilip bunların ruhuyla ilgilenilmesi, hâdiseler karşısında sâbit, değişmeyen ve devamlılık arz eden bir karakter salabetini ifade eden sünnet ${ }^{46}$ üzerine yoğunlaşılması çok daha faydalı olacaktır. Bu bağlamda Hadislerle İslam'ın takip ettiği "fıkhî ihtilafları fıkıh kitaplarına bırakan ve daha ziyade konuların hikmeti üzerinde duran" yöntemin ${ }^{47}$ isabetli olduğunu ifade etmeliyiz.

'Hadislerle İslam' ifadesinin ve anlayıșının, hadislerin tasnif dönemlerinde müesses fıkha ve itikada ya da bir başka ifadeyle re'y fıkhına ve itikadına alternatif olarak oluşturulan ale'l-ebvâb literatür içerisindeki en kapsamlı tür sayılan Câmic edebiyatıyla ${ }^{48}$ benzerlik taşıdığı, dolayısıyla ortalama okurların klasik hadis kaynaklarını okumada karşı karşıya kaldıkları sorunları tümüyle izale edemeyeceği kanaatindeyiz. Hassaten bilimsel çalışmalarda ismin müsemmadan ayrı düşünülemeyeceği açıktır. Nitekim DİB'in 'Hadislerle İslam'ında eserin temel amacı bazen 'Hz. Peygamber'in tutum ve davranışları, söz ve hadislerindeki mesajı, örnekliği sade ve anlaşılır bir dille günümüz insanına ulaştırmak' şeklinde takdim edilirken bazen 'hadislerin halka ulaştırılması'ndan söz edilmekte, müsemma/muhteva ise 'hadislerin hadislerle yorumu' olarak belirlenmektedir. ${ }^{49}$ Özetle hadis-sünneti hal-

43 Ahmet Yücel ve Cemal Ağırman da aynı ifadeleri kullanmaktadırlar. bk. https://www.youtube.com/watch?v=4sJhCQf9ZzA

44 Mesela namazla ilgili “... ve namazı kıl! Muhakkak ki namaz, hayâsızlıktan ve kötülükten alıkoyar” buyurularak utanma duygusunun ve kötülüklerden uzak durmanın namaz sayesinde bir karakter haline gelmesi istenmektedir. bk. el-Ankebût 29/45. Hadislerde de benzer vurgu söz konusudur.

45 Ali Yardım, Hadis I-II (İstanbul: Damla Yayınevi, 2017), 31.

46 bk. Yardım, Hadis I-II, 32.

47 Hadislerle İslam, 1/44.

${ }^{48}$ Hadislerin fıkhını merkeze alan Sünenlerin ve Câmilerin oluşum sebepleriyle ilgili geniş bilgi için bk. Mehmet Görmez, Sünnet ve Hadisin Anlaşılması ve Yorumlanmasında Metodoloji Sorunu (Ankara: TDV Yayınları, 1997), 105-107; Ömer Özpınar, Hadis Edebiyatının Oluşumu (Ankara: Ankara Okulu, 2005), 157-167.

${ }^{49}$ bk. Hadislerle İslam, 1/42, 44, 144. 
ka arz etme hedefiyle telif edilen en son ve kapsamlı maruz çalışma olan DİB'in bu eserinin, dini ilimlerde belirli bir müktesebatı haiz kimselerin azade kalamayacakları bir çalışma olmakla birlikte hadis-sünnet ayırımı gözetilmediğinden ortalama okurlar için beklenen faydayı tam olarak sağladığını söylemek zordur.

Hadis-Sünnet Ayırımı ve Hadislerden Ziyade Sünnetin Arz Edilmesi șeklindeki önerinin, söz ıssı Rasûl-i Ekrem'in (sav) hiçbir ifadesinin ya da onu ve davranışlarını tahkiye eden anlatıların avama ulaştırılmaması anlamına gelmeyeceğini belirtmek isteriz. Zira cevâmi'u'l-kelim nitelikli ve hikmet yüklü hadislerden insanları mahrum etmek hem doğru olmaz hem de mümkün değildir. Başkalarına ait pek çok özlü sözü öğrenen ve kullanan insanlar elbette rahmet elçisinin (sav) ve seçkin sahabesinin sözlerini evleviyetle duymak veya okumak isteyeceklerdir. Burada anlatılmak istenen, her alanda ayetlerin ve hadislerin yanı sıra din ulularının ${ }^{50}$ yorumlarından hareketle tespit edilecek olan çağcıl bir Nebevî paradigmanın ya da Nebî'nin (sav) örnekliği ve rehberliği demek olan sünnetin merkeze alınması, sıhhati ve delaleti sarih olan cevâmi 'u'l-kelim nitelikli ve hikmet dolu ya da doğrudan bir sünneti ifade eden hadislerin arzıdır. Ayrıca her ne kadar klasik kaynaklarda mevzu hadis ifadesi kullanılıyor olsa da hadislerin halka arzında uydurma hadis yerine uydurma rivayet tabirinin tercih edilmesinin daha doğru olacağını belirtmek isteriz.

Son olarak önerimizin hem daha somut hale gelmesi hem de kültür tarihimizde bir karşılığının olduğuna işaret etmek için aynı dönemde kaleme alınan iki eseri bir örnek üzerinden mukayese etmek istiyoruz. Eserlerinin muhteva bakımından bir nevi 'Kur'an tefsirinden ve nebevî hadislerden" oluştuğu kabul edilen Mevlânâ'nın (ö. 672/1273),51 konuları işlerken hadisleri nakletmekten ziyade hadislerin işaret ettiği sünneti çoğu zaman hadisten mülhem olan ve sünneti ifade eden özlü bir cümleyle ve bazen de cevâmi'l-kelim nitelikli bir hadis metniyle Rasûlullâh'ın (sav) sünnetlerini arz ettiği görülmektedir. Onunla aynı dönemde yaşayan Münzirî (ö. 656/1258) ve Nevevî (ö. 676/1277) gibi hadisçiler ise etTerğîb ve't-terhîb ve Riyâzu's-sâlihîn isimleriyle halka yönelik kaleme aldıkları eserlerin muhtevalarını tamamen hadis metinlerinden oluşturmuşlardır.

İmam Nevevî Riyâzu's-sâlihîn'in ilk bölümünde ihlas ve ebeveyne hürmet gibi erdemleri ele alırken önce bazı durumlarda halvet ve uzletin müstehap oluşuna ve hemen peşinden de celvetin/ihtilatın faziletine dair iki ayrı bab açarak ilkinde bir âyete yer verdikten sonra sahabi ravileri ve muharricleriyle birlikte beş hadis

${ }^{50}$ Din uluları=din büyükleri ifadesi merhum Koçkuzu hocamıza ait olup başta sahabe olmak üzere selef alimleri kastedilmektedir. bk. Ali Osman Koçkuzu, Mesnevî'de Hz. Peygamber -Hadis-i Şeriflere Atıflar(Konya: Rûmî Yayınları, 2006), 21-22.

51 Bu tespit, Mesnevî uzmanı İsmail Ankaravî’ye aittir. bk. İsmail Rusûhî Ankaravî, Mesnevî-i Şerif Şerhi (İstanbul, 1289), 1/1. 
zikretmiş, ikincisinde ise âyete-hadise başvurmadan kısa bir yorumla yetinmiştir. ${ }^{52}$ Mesnevî'de ise uzlet ve ruhban hayatının değil de toplum içinde yaşayıp insanlara faydalı olmanın sünnet olduğu Avcı ile Kuş hikayesiyle izah edilirken şu başlık kullanılmaktadır: "Mustafa'nın -ona selâm olsun- 'İslâm'da ruhbanlık yoktur diye' ümmetine yasakladığı ruhbanlığın anlamı hakkında kuşun avcıyla tartışması." Muhtevasındaki beyitler ise şöyledir: "Kuş, ona: Efendi, dedi, yalnız başına oturma; Ahmed'in dininde ruhbanlık iyi değildir. O Peygamber ruhbanlığı menetti, niye böyle bir bid'ate kapıldın a fodul! Cumaya gitmek, namazda cemaat olmak, iyiliği emredip kötülükten sakındırmak şarttır. Kötü huyluların sıkıntısını çekip sabretmek, bulut gibi insanlara yarar sağlamak şarttır. 'İnsanların hayırlısı, insanlara yararı olandır', a babacığım! Taş değilsen, kerpiçle arkadaşlığın niye? Merhamet edilmiş ümmetin arasında ol. Ahmed'in sünnetini bırakma, hükmüne uy! ... 0 muhteșem Peygamber, bunun için ruhbanlığı ve dağlarda halvete çekilmeyi yasakladı."53 İslam'da ruhbanlığın olmadığı hükmü, ayetlerden ve hadislerden elde edilen bir sonuçtur ki Celâleddî er-Rûmî bu anlatısında o naslara yer vermeksizin sonuca odaklanmaktadır. ${ }^{54}$

Münzirî ve Nevevî'nin mezkûr eserlerini Kütüb-i sitte'den veya bunlara yapılan şerhlerden ayıran yegâne fark, sahâbî ravisi dışındaki isnadın hazfedilip rivayetlerin kaynağına işaret edilmesi ve aynı konudaki farklı kaynaklarda yer alan güvenilir hadislerin bir araya getirilmesidir. Yani sünnetten çok hadisler ön planda olup hadis, rivayet, râvî, sahih-zayıf gibi belirli bir altyapıyla ancak anlaşılabilecek terminolojik ifadeler söz konusudur. Dolayısıyla her ne kadar halka yönelik yazılmış olsalar da bu eserlerden herhangi bir dini altyapısı olmayanların istifade imkânı tartışmalıdır. Şüphesiz Mevlânâ'nın yönteminin de hadis ilmi açısından mahzurları vardır, fakat ehl-i hadisin gayretleriyle bunlar telafi edilebilir. Asıl maksat Rasûl-i Ekrem'in (sav) örnekliğinin geniş halk kitlelerine ulaştırılması olduğuna göre, mahzurlu tarafları giderilmek suretiyle Hz. Pîr'in izlediği yöntemin sürdürülmesinin ve geliştirilmesinin daha yararlı olacağı görüşündeyiz. Nitekim etTerğîb ve't-terhîb ile Riyâzu's-sâlihîn, hadisçiler dışında yalnızca belirli bir bilgi düzeyindeki müminler arasında biliniyor ve okunuyorken, Mesnevînnin evrensel bir hüviyet kazanması da kanaatimizi desteklemektedir.

52 bk. Ebû Zekeriyyâ Yahyâ b. Şeref b. Mürî en-Nevevî, Riyâzü's-sâlihîn, thk. Şuayb el-Arnavut (Beyrut: Müessesetü'r-Risâle, 1998), 209-210.

53 Celâleddîn Muhammed b. Muhammed er-Rûmî Mevlânâ, Mesnevî, ed. Mehmet Birekul, çev. Derya Örs - Hicabi Kırlangıç (Konya: Konya Büyükșehir Belediyesi Yayınları No:125, 2007), 6/47 (478-483. beyitler), 6/177 (2620. beyit).

54 "İrfan Medeniyetinde Mevlânâ ve Mevlevîlik" adlı bir kitap projesinde yer almak üzere tarafimızdan hazırlanan "Mevlâna ve Aktüel Hadisçilik (Asrın İdrakine Sünneti Söyleten Adam: Mevlâna)" adlı makalede çok sayıda örnek verilmiştir. 


\subsection{Sünnetin Bir Zihniyet ve Dünya Görüşü Olarak Takdimi}

İlahiyat/İslami İlimler tahsiline yeni başlayan öğrenciler için durum tespiti yapmak üzere ilk derslerde pek çok akademisyen hadisçi gibi yönelttiğimiz 'sünnet deyince ne anlıyorsunuz ve aklınıza gelen bir sünnet söyleyin' şeklindeki basit anketlerden anlaşllan odur ki ortalama kültüre sahip Müslümanlar sünnet denilince Hz. Peygamber'in yeme-içme veya giyim-kuşam gibi konulardaki tasarruf ve tavsiyelerini anlamaktadırlar. ${ }^{55}$ Gerçi farklı sosyal kesim denekleri üzerinde Malatya ilinde yapılan alan bir araştırmasında bu hipotezin doğrulanmadığı, tam tersine sünnetin niteliği konusunda toplumun yeterli bir ortak bilgiye sahip olduğu ve sünneti farz/vacibin dışında kalan fiiller ya da tabağı sünnetleme ve sünnet olmak tarzı gelenekler şeklinde anlayanların marjinal düzeyde olduğu sonucuna varılmıştır. ${ }^{56}$ Fakat anketin güvenirliği ve başka bölgelerde yapılacak araştırmaların benzer sonucu verip vermeyeceği bir tarafa, yukarıda ifade ettiğimiz üzere yolsuzluğun en fazla olduğu ülkelerin Müslümanların ekseriyette olduğu coğrafyalardan oluștuğunu gösteren enternasyonal endeksler Hz. Peygamber'in örnekliğinin bir zihniyet ve dünya görüşü ya da yaşam felsefesi haline getirilemediğini ortaya koymaktadır. Bu sonucun oluşmasında pek çok faktörün yanında sünnetin toplum nazarında ifade ettiği anlamın da etkili olduğunu düşünüyoruz.

Yakın zamana kadar Müslümanların kahir ekseriyeti temel dini bilgilerini ailede ve camide genellikle ilmihale dayalı olarak ve sözlü aktarımla öğrenirken, zorunlu eğitimin on iki yıla çıkmasıyla birlikte zorunlu ve seçmeli dersler sayesinde örgün eğitim içerisinde bu bilgileri almalarına imkân doğmuştur. İlmihaller genellikle mükellefin fiilleri veya ahkamı konusuyla başlamakta ve davranışlar hüküm itibariyle farz, vacip, sünnet, müstehap, mübah, haram, mekruh ve müfsid şeklinde sekizli bir taksime tabi tutularak sünnet "farz ve vacip olmaksızın yapılması istenen" fiiller olarak izah edilmektedir. ${ }^{57}$ Diyanet ilmihalinde ise beşli taksim benimsenmiş ve ikinci sıradaki mendubun alt başlığı olarak sünnet ve müstehap kavramları yer almıştır. Açıklamada yer alan ifadeler esasen ilmihal geleneğinin sünneti ele alış biçiminin sorunlu olduğuna işaret etmekte ve hatalı anlamanın önüne ge-

55 Son üç yıldır yeni bașlayanlara yönelik ilk derslerde yaptığım anketlerde adil olmak, dürüstlük, kul hakkı yememek, yetimlere kol-kanat germek, yardımlaşmak, güzel ahlaklı olmak gibi sünnetleri söyleyebilenlerin sayısı iki üçü geçmedi.

56 Ahmed Ürkmez, "Sosyal Kesimler ve Sünnet Algıları Araștırması: Malatya (Hadis Alan Yorumu)", Süleyman Demirel Üniversitesi İlahiyat Fakültesi Dergisi 2012/1/28 (2012), 104-105. Anketörler aracılığıyla yapılan bu araștırmanın sonuç bölümünde yer alan “...farklı pek çok sosyal kesimin sünnet kavramının içeriğine oldukça hakim bulunduğunu görmek ne kadar sevindirici ise, pratik ahlak boyutunda sünnete dayalı amelden uzak kalındığı gerçeği de o kadar üzücüdür" ifadesi anketin güvenirliğini sorgular niteliktedir.

${ }^{57}$ Mesela bk. Muhammed (Mehmed) Zihnî, Nimet-i İslam (İstanbul: Şirket-i Mertebiye Matbaası, 13201897), 5; Komisyon, TDV İlmihal (Ankara: Türkiye Diyanet Vakfi, 2020), 1/163; Lutfi Şentürk Seyfettin Yazıcı, İslam İlmihali (Ankara: Diyanet İşleri Başkanlı̆̆ı, ts.), 86; Hamdi Döndüren, İslam İlmihali (İstanbul: Erkam Yayınları, 1991), 49; Fazilet Neşriyat (ed.), Resimli Muhtasar İlmihal (İstanbul: Fazilet Neşriyat ve Ticaret A.Ş., 2020), 52. 
çilmeye çalışılmaktadır. "Sünnet, Hz. Peygamber'in söz, fiil ve onayının genel adı olup fıkıh usulünde Kur'an'la birlikte İslâm'ın aslî iki kaynağını ve delilini teşkil eder. Fürû-ı fikıhta, özellikle de teklifî hüküm açısından sünnet ise, Hz. Peygamber'in farz ve vâcip kapsamı dıșında kalan yani kesin ve bağlayıcı olmaksızın tavsiye ve örnek olma niteliğini taşıyan söz ve fiillerinin genel adıdır. Hanefîler'in dışındaki fakihler, Allah ve Resulü'nün kesin ve bağlayıcı olmayan tarzda yapılmasını istediği veya tavsiye ettiği fiillerin tamamını kapsamak üzere mendup terimini kullanırlar. Diğer bir ifadeyle, Kur'an ve hadislerden gerek doğrudan gerekse dolaylı olarak bir fiilin yapılmasının kesin ve bağlayıcı olmayan tarzda istendiği yani tavsiye edildiği sonucu çlkarılabiliyorsa, bu tür fiillere topluca mendup denilir." 58 Sünnetin hüdâzevâid, müekked-gayr-i müekked ve aynî-kifâî gibi ayırımlara tabi tutuluşu ise daha ziyade belirli bir ilmi alt yapısı olanların takrir ettiği fikıh ve usulü kitaplarında söz konusudur. ${ }^{59}$

Diyanet İşleri Başkanlığı marifetiyle camilerde ve Kur'an kurslarında yürütülen yaygın eğitimde okutulan ders kitaplarında da ilmihal bakış açısı söz konusu olup öğrencilerin sünnet kavramıyla ilk karşılaşmaları yine mükellefin fiilleri/davranışları konusuyla gerçekleşmiş olmaktadır. ${ }^{60}$ Örgün eğitimde takip edilen temel dini bilgiler ders kitaplarında ise ilmihal kültürünün terk edildiği, insan davranışlarını kategorize eden ve sünneti "farz ve vacip olmaksızın yapılması istenen fiiller" șeklinde tanımlayan ilmihal anlayıșı yerine bireysel ve toplumsal olarak sosyo-ekonomik hayatta ve ahlak alanında Hz. Peygamber'in örnekliğinin ön plana çıkartılmaya çalışıldığı gözlemlenmektedir. ${ }^{61}$

Fıkıhçların insan davranışlarını kategorize ederken zorunlu olmayan ama tercih ve teşvik edilen eylemlerini sünnet olarak adlandırmalarının ve ardından da mendub, tatavvu, müstehap, nafile, müekked, gayr-i müekked vs. alt kategorilere ayırmalarının, ${ }^{62}$ hayatın farklı alanlarında Nebî'yi (sav) örnek almada ve rehber edinmede bir takım zihin bulanıklıklarına, karışıklıklara ve tesahüle yol açmadığını söylemek zordur. Üstelik hüküm bağlamında fıkıhta kullanılan sünnet kavramını

58 Komisyon, TDV İlmihal, 1/166-167.

59 bk. Ferhat Koca, "Sünnet" (İstanbul: Türkiye Diyanet Vakfı İslam Araştırmaları Merkezi, 2010), $38 / 154$.

${ }^{60}$ Mesela bk. Seyfettin Yazıcı, Temel Dini Bilgiler (Ankara: Diyanet İşleri Başkanlığı Yayınları, 2012), 32; Mehmet Emin Özafșar - Recai Doğan (ed.), Temel Íslam Bilgileri -Íbadetim- (Ankara: Diyanet İșleri Başkanlığı Yayınları, 2009), 11.

61 Mesela bk. Mustafa Yılmaz (ed.), Temel Dini Bilgiler (İslam 1) Ortaokul ve İmam Hatip Ortaokulu Ders Kitabı (Ankara: Milli Eğitim Bakanlığı Devlet Kitapları, 2019); Sabahattin Nayir (ed.), Temel Dini Bilgiler (İslam 1) Ortaöğretim Ders Kitabı (Ankara: Milli Eğitim Bakanlığı Devlet Kitapları, 2019); Abdullah Açık, Temel Dini Bilgiler (İslam 2) Ortaöğretim Ders Kitabı, ed. Mustafa Yılmaz (Ankara: Milli Eğitim Bakanlığı Devlet Kitapları, 2019); Ahmet Özdemir, Temel Dini Bilgiler -Anadolu İmam Hatip Lisesi- (Ankara: Milli Eğitim Bakanlı̆̆ı Devlet Kitapları, 2018).

62 Fıkıhçıların ve usulcülerin sünnet tariflerinin değerlendirilmesi için bk. Cemal Ağırman, "Hadisçilerin Sünnet/Hadis Tarifinde Yer Alan Vasıf Kavramı Üzerinde Bir Yorum”, Cumhuriyet Üniversitesi İlahiyat Fakültesi Dergisi 2 (1998), 102-104. 
mendub, nafile ve tatavvu gibi terimlerle karşılama imkânı da mevcuttur. Nitekim Kırbaşoğlu da Sünnet'in bu şekilde kullanımı için herhangi bir zaruretin bulunmadığını ve hüküm bağlamında aynı manayı veren diğer terimlerin tercih edilmesinin daha doğru olacağını dile getirmiştir. ${ }^{63}$

Hadis ile sünneti eş anlamda kullanıp Allah Rasûlü'nün (sav) beşeri yönünü de tanımın içine dahil eden hadisçilerin tutumunun da Sünnet'in bir model, yaşam tarzı ve dünya görüşü şeklinde anlaşılmasını ve içselleştirilmesini gölgelediğini söylemek durumundayı. Sorun, Hz. Peygamber'in biset öncesi hayatı ile yaratılış hususiyetlerinin, Sünnet'in niteliğini daha iyi anlama ve ittibaya katkı sağlaması ${ }^{64}$ açısından hadisin tanımına dahil edilmesinde değil, bu aynı tanımın sünnet olarak da takdimindedir. Bu anlayış, ister istemez sünneti bağlayıcılık açısından bir tasnife ve kategorik ayırıma tabi tutmayı beraberinde getirmektedir. Nitekim İbn Kuteybe'nin (ö. 276/889) sünnetleri bağlayıcı olup olmamasına göre üç gruba ayırmasından sonra daha çok fikıh usulcüleri tarafından pek çok sınıflandırma ortaya konmuştur. ${ }^{65}$ Bağlayıcılık bakımından yapılan sünnet tasniflerinin medarını, Şah Veliyyullah Dihlevî’nin (ö. 1762) tasnifinden ${ }^{66}$ de anlaşılacağı üzere Hz. Peygamber'in tasarruflarının risaletle ilişkisi oluşturmaktadır. Bunun da temelinde 'Sünnet nedir?' sualine verilen cevabın yani sünnet tanımının yattı̆̆ı söylenebilir. 0 halde yukarıda ifade edildiği üzere Kırbaşoğlu'nun hadis ile sünneti ayıran ve üzerinde görece bir konsensüs sağlanan tanımına "Sünnet, Hz. Peygamber'in risalet görevi gereği kendi döneminde..."67 şeklinde küçük bir ilave yapılmak suretiyle sünnetin bağlayıcılık yönünden kategorizesine duyulan ihtiyaç belirli ölçüde giderilebilir. Zira bağlayıcılık tasnifleri her ne kadar ilmi perspektiften bir gereklilik olarak addedilse, hatta bir-iki kişi dışında hadisçilerin böyle bir sınıflandırma yapmamaları eleştiri konusu olsa da ${ }^{68}$ avam açısından bakıldığında, furû-i fıkıhtaki sünnet anlayışında ortaya çıkan mahzurun bir benzeri burada da söz konusu olabilmektedir. Bir zihniyet ve dünya görüşü olarak takdim edilecek olan Sünnet'i, bağlayıcı olan-olmayan ya da yapıldığında sevap alınan ama terkinde mahzur görülmeyen bir anlayış ile örtüştürmek oldukça zordur.

\footnotetext{
63 bk. Kırbașoğlu, İslam Düşüncesinde Sünnet, 93.

64 bk. Ağırman, "Hadisçilerin Sünnet/Hadis Tarifinde Yer Alan Vasıf Kavramı Üzerinde Bir Yorum”, 109110.

65 Bağlayıcılık açısından sünnet tasnifleri hakkında geniş bilgi için bk. Kırbaşoğlu, İslam Düşüncesinde Sünnet, 80-95; Talat Sakallı, "Sünnet'in Bağlayıcılık Açısından Taksimi”, Süleyman Demirel Üniversitesi İlahiyat Fakültesi Dergisi 2 (1995), 39-102; Murat Şimşek, İslam Hukukunda Bağlayıcılık Bakımından Hz. Peygamber'in Íctihad ve Tasarrufları (Ankara: Türkiye Diyanet Vakfı, 2010), 43-115; Hayrettin Karaman, "Bağlayıcılık Bakımından Rasûlullah'ın Davranıșları", Hz. Peygamber ve Aile Hayatı (Tartışmalı İlmi Toplantılar, İstanbul: İlmî Neşriyat) (Erişim 09 Temmuz 2021).

66 bk. Şâh Veliyyullah ed-Dihlevî, Huccetullâhi'l-bâlig̉a, thk. Muhammed Şerif Sükkar (Beyrut: Dâru İhyâi'l-Ulûm, 1990), 1/371.

67 Tanım için bk. Kırbaşoğlu, İslam Düşüncesinde Sünnet, 107.

68 bk. Kırbaşoğlu, İslam Düşüncesinde Sünnet, 79-95.
} 
Sahabe ve tâbiîn dönemlerinde Hz. Peygamber'in tasarruflarına kaynak ve nitelik yönünden zahiri, fikhî ve ictihadî gibi farklı yaklaşımlar ${ }^{69}$ söz konusu olmakla birlikte Sünnet kavramının kelamî konularda sapıklığın/bid'atin karşıtı olarak ve fıkhî bağlamda da hem mendubu/nafileyi hem de vacibi/farzı içine alacak şekilde kullanıldığı, ilimlerin teşekkülüyle birlikte maksada göre kavramın farklı tarifleri yapıldığı kabul edilmektedir. ${ }^{70}$ Nitekim Hz. Ömer'in "Sünnet, Allah'ın ve Rasûlü'nün Sünnet kıldığıdır. Yanlış görüşleri, ümmete Sünnet diye sunmayın!"71 dediği, Mekhûl'ün (ö. 112/730) de birisi uyulması zorunlu olan ve terki de küfrü gerektiren Sünnet-i farîza ve diğeri de uymanın fazilet olduğu ve terkinin ya da uymamanın harec/sakıncalı sayıldığı Sünnet-i fazîle şeklinde Sünnet'i tavsif ettiği kaynaklarda yer almaktadır. ${ }^{72}$ Abdullah b. Ömer (ra) ile tabiinden bir şahıs arasında cereyan eden diyalog da fevkalade câlib-i dikkattir: "Kurban kesmek vacip midir?" şeklinde bir vatandaşın kendisine yönelttiği soruya "Rasûlüllah (sav) da Müslümanlar da kurban kestiler" cevabını veren Abdullah b. Ömer (ra), adamın ısrarla kurbanın hükmünü sorması üzerine "Anlamıyor musun be adam! Rasûlüllah (s.a.v.) da Müslümanlar da kurban kestiler" karşılığını vermiştir. ${ }^{73}$ Görüldüğü gibi İbn Ömer (ra) Kur'ân'dan ve hadislerden deliller serdederek kurbanın hükmüne dair bilgi vermeyi değil, Rasûl-i Ekrem'in (sav) kurban hususundaki örnekliğini yani muhatapta davranışa dönüşmesi gereken boyutunu öne çıkarmayı tercih etmiştir. Zira elbette bir şeyin hükmüne dair bilgi önemlidir ve sahih bilgiyi üretmek ulemanın görevidir, lakin asıl hedef o bilginin davranış haline gelmesidir. Nitekim bugün için de eksikliği daha ziyade hissedilen husus, adalet, liyakat, dürüstlük, doğruluk ve kul haklarına riayet gibi bilgisine sahip olunan ahlaki değerlerin hem birey hem de toplum bazında arzu edilen düzeyde davranış haline getirilememesidir. ${ }^{74}$

69 Sahabenin Sünnet anlayıșı ve farklı yaklaşımları için bk. Erul, Sahabenin Sünnet Anlayışı, 153 vd.; Tabiinin sünnete bağlayıcılık açısından yaklaşımları için bk. Ulu, Tâbiûnun Sünnet Anlayıșı, 165-178, $222 \mathrm{vd}$.

70 bk. Muhammed Cemâlüddîn b. Muhammed el-Ḳâsimî, Kavấ'ldü't-taḥdîs min fünûni muștalaḥı'l-hadîs (Beyrut: Dâru Kütübi'l-İlmiyye, ts.), 146; Ulu, Tâbiûnun Sünnet Anlayışı, 119-125.

${ }^{71}$ Ebû 'Omer Yûsuf b. 'Abdillâh b. Muhammed b. 'Abdilberr en-Nemerî İbn 'Abdilberr, Câmi'u beyâni'l'ilm ve faḍlih ve mâ yenbagîi fî rivâyetih ve hamlih, thk. Ebü’l-Eşbel ez-Züheyrî (Suudiarabistan: Dâru İbni'l-Cevzî, 1994), 2/1047.

72 bk. Ebû Muḥammed 'Abdullah b. 'Abdirraḥmân b. el-Faḍl ed-Dârimî, es-Sünen, thk. Hüseyin Selim Esed (S. Arabistan: Dârü'l-Muğnî, 2000), "Mukaddime”, 49; Ebû 'Omer Yûsuf b. 'Abdillâh b. Muhammed b. 'Abdilberr en-Nemerî İbn 'Abdilberr, el-'istizkâru'l-câmi' li-mezâhibi fukahâi'l-emșâr ve 'ulemâi'l-aktâr fîmâ tedammenehü'l-Muvatta min me'âni'r-re'y ve'1-âsâr ve șerhu zâalike küllih bi'l-îcâzi ve'l-iḩtișâr, thk. Sâlim Muḥammed 'Ata, Muḥammed 'Ali Mu'avvaḍ (Beyrut, 2000), 2/57.

73 Ebû 'Îsâ Muhammed b. 'Îsâ b. Sevre es-Sülemî et-Tirmiẓ̂, el-Câmi'u'l-muhtașar mine's-sünen an Rasûlillâh ve ma'rifetu'ș-șahîh ve'l-ma'lûl ve mâ 'aleyhi'l-'amel, thk. Beșșâr 'Avvâd Ma'rûf (Beyrut: Dâru'l-Ğarbi'l-İslâmî, 1998), "el-Edâhî", 11; Ebû 'Abdillâh Muhammed b. Yezîd Mâce el-Kazvînî İbn Mâce, es-Sünen (Riyad: Dâru's-Selâm, 1419), "el-Edâhî", 2.

${ }^{74}$ Konuyla ilgili geniş değerlendirme için bk. Musa Erkaya, “Hz. Peygamber (sav)'in Örnek Ahlâkının Günümüze Taşınmasında Hadis/Sünnetin Rolü”, 7-8 Mayıs 2010 Modern Çağda Ahlak Sempozyumu (Modern Çağda Ahlak, Konya: Sebat Ofset Matbaacılık, 2012), 350. 
Netice olarak günümüz insanına, mükellefin farz ve vacip olmayarak yaptığı fiillerine tekabül eden hükümler için fıkıhçların ve hadis ile sünneti aynileştirip sonra da bağlayıcı olan-olmayan şeklinde Sünnet'i kategorizeye muhtaç kılan hadisçilerin Sünnet'e yükledikleri anlamlar öne çıkartılmadan, Allah'ın insanlığa rol model/üsve-i hasene olarak takdim ettiği ve muhteşem bir ahlakla nitelendirdiği ${ }^{75}$ Nebîyy-i Zîşânın (sav) risalet görevi gereği itikat, ibadât, ahkam ve ahlak olmak üzere hayatın her alanında ortaya koyduğu örnekliğin bir zihniyet ve dünya görüşü ya da hayat felsefesi olarak arz edilmesi düşüncesindeyiz. Dini ilimler tahsili bulunmayan sevâd-ı azama sunulacak olan bu Nebevî yaşam ya da tarikat-ı Muhammediyedeki Sünnet, farz-mendub ve helal-haram gibi bütün ahkamın yanı sıra ahlaki erdemleri ve değerleri muhtevi çatı bir anlayışı yansıtmalıdır. Ulema için anlamlı ve de gerekli sayılan mezkûr isimlendirmelerin ve tasniflerin, halk nazarında Sünnet'in mehabetini azaltan bir fonksiyona dönüșebileceği göz ardı edilmemeli, anlama ve uygulama bakımından zihin karışıklığına mahal verilmemelidir.

\section{3. Şekil-Mânâ ve Sûret-Ruh Dengesinin Kurulması ve Gözetilmesi}

Hukukilik-kanunilik ya da helallik-yasallık çağımızın önemli dilemmalarından ve tartışmalarından birisidir. Mer'î mevzuata uygun olan ya da yasal sayılan her şeyin hakka ve hukuka uygun olmayabileceği veya helal görülemeyebileceği şeklinde son dönemlerde Alev Alatlı'nın alevlendirdiği söylem, ${ }^{76}$ esasen geleneğimizdeki fetva-takva ikileminin hukuk alanına taşınmasıdır. Bu arada İslam hukukunun 'ahlâkın kamu otoritesinin maddî yaptırımına bağlanmış hali' olduğundan ontolojik olarak fetva-takva ayrımından söz edilemeyeceği ve pratikte var olan böylesine bir ikilemin fetva ve müftinin öznel durumlarından kaynaklandığı düşüncesine katıldığımızı belirtmek isteriz. ${ }^{77}$

Şüphesiz ibadet-i mersumelerden, muamelelerden ve cezalardan ya da kısaca ubudiyete sarılma konusundaki emirlerden oluşan şeriat, ${ }^{78}$ İslam'ın sûreti/zâhiri olup ihmal edilemez ama din sâdece formel ya da zâhirî hükümlere de indirgenemez. Bu yüzden mesela Rabbe yaklaşmanın yolu olarak secdeyi yani namazı gördüğünden Mevlânâ ${ }^{79}$ arınmak ve istikamet üzere kalmak için namazların sürekli kılınmasını ve böylece namaz ehli olunmasını tavsiye ettikten ${ }^{80}$ sonra ruhsuz ve bilinçsiz yapılan ibadetlerin Müslümanları kurtarmaya yetmeyeceğini son derece çarpıcı bir şekilde anlatmaya çalışır: "Ey surete tapan! Var git, anlamı

75 bk. el-Ahzâb 33/21; el-Kalem 68/4.

76 Alev Alatll, “Her yasal olan hak helal değildir. Mühim olan helalleşmektir.”, 2016.

77 Düşünce ve temellendirilmesine dair bk. Ahmet Yaman, "Fakih ve Ahlâk - Fıkıh Etiği Üzerine Bazı Notlar -", Usûl İslam Araştırmaları Dergisi 26 (2016), 8, 18.

78 bk. 'Abdülkerim b. Hevâzin b. 'Abdülmelik el-Ḳuşeyrî, er-Risâletü'l-Ḳuşeyriyye, thk. 'Abdülḥalim Maḥmud, Mạ̣mud b. eş-Şerîf (Kahire: Dârü'l-Maârif, ts.), 82.

${ }^{79}$ bk. Mevlânâ, Mesnevî, 2/81 (1205. beyit).

${ }^{80}$ bk. Mevlânâ, Mesnevî, 1/264 (3796. beyit). 
bulmaya çalış. Çünkü anlam, suret bedeni üzerinde kanat gibidir. Anlam ehliyle otur kalk da hem ihsanlar elde et hem de delikanlı ol. Anlamsız can, şu bedende hiç kuşku yok ki kınındaki tahta kılıç gibidir. Kında bulunduğu sürece değerlidir. Kından çıktı mı yakılacak bir araç olur. Tahta kılıcı savaşa götürme; işin eyvah olmadan önce bir bak."81 Şekil-mânâ dengesini iyi kuran Mevlânâ, Allah sevgisinin sadece söylemde kalmayıp mutlaka dışa yansıması gerektiğini ve bu dışa yansımanın da sâlih ameller olduğunu ise şöyle anlatmaktadır: "Eğer yalnız mânaya ait anlatış yeterli olsaydı, âlem halkı tamamen ișten güçten kalır, âlemin nizamı bozulur giderdi. Sevgi, düşünce ve mânadan ibaret olsaydı senin oruç ve namazının zâhiri suretleri de kalmaz, yok olurdu."82 Aynı dengeyi, "Müslümanam diyen kişi şartı nedür bilse gerek - Tangrınun buyrugun tutup beş vakt namaz kılsa gerek" ${ }^{83}$ ve "Bir gez gönül yıktın ise, kıldığın namaz değil - Yetmiş iki millet dahi, elin yüzün yumaz değil" 84 diyen Yûnus'ta da görmek mümkündür. Esasen asırlar önce yaşamalarına rağmen Ahmed Yesevî (ö. 562/1166), Hacı Bektaş (ö.669/1270), Ahî Evren (659/1261), Mevlânâ (ö.672/1273) ve Yunus Emre (ö. 720/1320) gibi simaların yorumlarının hala geçerli akçe oluşunda, birisi bu dile getirmeye çalıştığımız zâhir-bâtın dengesi ve diğeri de somutlaştırarak anlatım olmak üzere iki hususiyetin etkili olduğunu düşünüyoruz. Elbette başka etmenler de söz konusudur ve konu çok boyutlu olarak ele alınabilir. Lakin șer'î hükümlerin bihakkın ifasını yani şeriatı dört katlı binanın giriş katı olarak değerlendiren ve diğer katlarla (tarikat-hakikatmarifet) birlikte İslam binasının tamam olacağını anlatmaya çalışan ${ }^{85}$ irfanî paradigmanın başat rol oynadığı kanaatindeyiz. Dolayısıyla Sünnet'in günümüz insanlığına arzında hadisçilerin, örneğin ibadetlerin bedene tealluk eden suretlerini fıkıh kitaplarına ve mânevî ya da bâtinî boyutlarını da tasavvufî eserlere bırakıp daha ziyade rivayet merkezli bir terğîb-terhîb şerh-yorum takip etmesi yerine, hicri VII. asırdaki büyük krizden çıkışta çok önemli bir rol oynayan Anadolu irfan geleneğinin şekil-mânâ ve sûret-ruh dengeli anlayıșını benimsemelerinin daha faydalı olacağı kanaatindeyiz. Böylece formel ibadetlerle ilgili âyetlerde ve hadislerde "oruçla takvaya ulaşmak, namazla hayasızlıklardan ve çirkinliklerden arınmak, zekatla temizlenmek...” şeklinde gösterilen nihâî hedeflere ulaşılmasına ciddi bir katkı yapılmış olacaktır.

\footnotetext{
${ }^{81}$ Mevlânâ, Mesnevî, 1/77 (711-715. beyitler).

82 bk. Mevlânâ, Mesnevî, 1/194 (2623-2624. beyitler).

83 bk. Yûnus Emre Dîvânı (Ankara: T.C. Kültür ve Turizm Bakanlığı Kütüphaneler ve Yayımlar Genel Müdürlüğü, ts.), 108.

${ }^{84}$ Burhan Toprak, Yunus Emre Divanı (Eskişehir: Odunpazarı Belediyesi, 2006), 112.

85 bk. Abdullah Kahraman, "Yunus Emre Dîvân'ında Şerîat, Tarîkat, Hakîkat ve Marîfet (Dört Kapı)", Kocaeli İlahiyat Dergisi 1/1 (2017), 1-18.
} 


\subsection{Sünnetin Sunumunda Somutlaştırma/Alegorik Anlatımdan Yararlanıl- mall}

ed-Dîn'in sahibi olan Allah Teâlâ insanlığa İslam'ı hayret verici olağanüstü bir üslupla (mu'ciz) sunmaktadır ki Kur'ân'ın yarısından fazlasını oluşturan kıssaların ve mesellerin bu iccâzî üslûbun önemli bir parçası olduğunda şüphe yoktur. ${ }^{86}$ Allah'ın sıfatları, peygamberlik ve ahiret hayatı gibi inanca dair gaybî kavramlar olsun adalet-dürüstlük gibi dünyada fesadı önlemeye ve infak-yardımlaşma gibi insanlara faydalı olmaya matuf değerler bütünü olsun dindeki soyut kavramların Kur'an'da somutlaştırılarak anlatıldığı görülmektedir. Örneğin Allah'ın bilgisinin namütenahi oluşu ağaçlar-denizler temsiliyle, 87 iyi-kötü sözler köklü-köksüz ağaç metaforuyla, ${ }^{88}$ infak ve bereket de her başağında yüz tanenin bulunduğu yedi adet başak çıkaran bir tohum benzetmesiyle ${ }^{89}$ anlatılmaktadır.

Rasûlullâh'ın (sav) da vermek istediği mesajın daha iyi anlaşılması için zaman zaman teşbih, istiare ve mecaz gibi anlatım tekniklerini kullanmak suretiyle soyut bilgileri ve değerleri somutlaştırdığı malumdur. Hadislerde hibesinden dönenin kusmuğunu yiyen köpeğe benzetilmesi, ${ }^{90}$ ateşin odunu yakıp bitirmesi gibi hasedin de iyilikleri yok edeceğinin ifade edilmesi, ${ }^{91} \mathrm{~Hz}$. Âdem'den itibaren bütün Peygamberlerin bir binaya ve Hz. Muhammed'in de o binada eksik kalan bir tuğlaya benzetilmesi, ${ }^{92}$ insanoğlunda var olan tûl-i emel ile ecel ilişkisinin geometrik bir metaforla izahı, ${ }^{93}$ beş vakit namazla Müslümanın hatalarından temizleneceğinin nehir örneğiyle somutlaştırılmasi ${ }^{94}$, kulun tevbesine Allah'ın sevinmesinin çölde bir kişinin devesini kaybedip de bulunca duyduğu sevinç tablosuyla açılklanması, ${ }^{95}$ toplumun aynı gemide yolculuk yapan yolculara benzetilmesi ${ }^{96}$ gibi çok sayıda somutlaștırma örnekleri mevcuttur. Kur'ân'daki ve hadislerdeki temsili anlatılarda

86 Konuyla ilgili geniş bilgi için bk. Veli Ulutürk, "Kur'an-ı Kerim'de Meseller (Emsâlü'l- Kur'an) (I-II)”, Atatürk Üniversitesi İlahiyat Fakültesi Dergisi 11-12 (1993-1995), 74-100 ve 29-48; M. Suat Mertoğlu, “Üslûbu'l-Kur'ân”, Türkiye Diyanet Vakfı İslâm Ansiklopedisi (İstanbul: TDV Yayınları, 2012), 42/382; İdris Şengül, "Kıssa”, Türkiye Diyanet Vakfı İslâm Ansiklopedisi (İstanbul: TDV Yayınları, 2002), 25/498-501.

87 bk. Lokmân 31/27: "Yeryüzündeki bütün ağaçlar kalem olsaydı, deniz de -ardından ona yedisi daha eklenmek üzere- mürekkep olsaydı yine de Allah’ın sözleri tükenmezdi; Allah azîzdir, hakîmdir.”

88 bk. İbrahim 14/24-26.

89 el-Bakara 2/261.

90 Buhârî, "Hîbe", 14; Müslim, "Hibât", 1.

91 Süleymân b. el-Eş'as b. İshâak es-Sicistânî el-Ezdî Ebû Dâvûd, es-Sünen (Riyad: Dâru's-Selâm, 1419), "Edeb", 22.

92 Buhârî, "Menâkıb”, 18; Müslim, "Fedâil”, 20-23.

93 Buhârî, "Rikâk", 4; Tirmiẓ̂,, "Klyâmet", 22; Ayrıca bk. Selim Demirci, "Hadis Metnini Anlama/Somutlaștırma Çabasına Bir Örnek: Hz. Peygamber’in Emel-Ecel İlişkisine Dair Çizdiği Şekil”, FSM İlmi Araștırmalar İnsan ve Toplum Bilimleri Dergisi 6 (2015), 101-121.

94 Müslim, "Mesâcid”, 283.

95 Müslim, "Tevbe", 1-7.

96 Buhârî, "Şerike", 6. 
genellikle hayvanlardan bitki örtüsüne kadar İslam'ın ilk muhataplarının yaşadığı coğrafyanın dikkate alındığı görülmektedir.

Kur'an ve hadislerin üslup özeliklerinden birisinin de temsilî ya da örneklemeli anlatım olduğu açıktır. Mesel/emsâl kelimesinden'77 türetilen ve kısaca 'Aklî olanın hissi bir suret altında sunumu' şeklinde tanımlanan temsili anlatımda temel maksadın, 'Soyut ve ruha, akla uzak manaları anlayışa yaklaştırmak, kavratmak/takrib' olduğu söylenebilir. ${ }^{98} \mathrm{Bu}$ anlam ve maksadıyla temsili ya da örneklemeli anlatım, somutlaştırma ile eşanlama gelmektedir. Duyular veya imgelem ile algılanabilen gerçekliği ifade eden somut (müşahhas) kelimesinden türetilen somutlaştırma, dildeki soyut/mücerret kavramların somut kavramlardan yararlanarak anlatımı şeklinde tanımlanabilir. ${ }^{99}$ Tariflerden de anlaşılacağı üzere somutlaştırma ve temsili anlatım bir anlama ve yorumlama yöntemi değil, anlatım üslubudur. Türk Dil Kurumu sözlüklerinde örneklem olarak yer alan Haldun Taner'e ait cümle, Sünnet'in halka sunumunda faydalanılmasını önerdiğimiz anlatım üslubunu gayet güzel ifade etmektedir: "En soyut konuları çok çarpıcı somut örneklerle herkesin anlayacağı bir yalınlığa getirirdi." 100

Diğer taraftan Greklerin ve Yahudi-Hıristiyan din adamlarının kutsal metinlerdeki tutarsızlıkları bertaraf etmek üzere somutlaştırmayı bir anlama yöntemi olarak kullandıkları ve bunu da alegori olarak adlandırdıkları bilinmektedir. ${ }^{101}$ Başlangıçta dini metinlerin literal anlamı ile gizli manaları arasındaki farkı belirlemek için bir anlama ve yorum metodu şeklinde retoriğe bağlı olarak ortaya atılmiş olsa da Gadamer'in ifade ettiği gibi daha sonra teolojide alegorik yöntemden vazgeçilmiş ve daha nesnel yöntem arayışına gidilmiştir. ${ }^{102}$ Bununla birlikte klasik metinlerde 19. yüzyıla gelinceye kadar başat anlatım biçimi/tekniği ya da tar$\mathrm{zl} /$ üslubu olarak kullanılan ${ }^{103}$ ve bir fikrin ve davranışın veya erdemin kısacası soyut olan veya soyut tarafı ağır basan bir kavramın somutlaştırılarak anlatılması şeklin-

97 Mesela bk. el-Bakara 2/26 emsal er-Ra`d 13/17. Kelime müfret ve cemi haliyle Kur'an'da kırk civarında geçmektedir.

98 Sâdık Kılıç, "Kur’an ve Hadislerde Temsili Anlatım Örnekleri - İnsanî, İlahî ve Uhrevî Hakikatlerin Sunumu Bağlamında Semantik ve Pedagojik Bir Deneme”, İslâmî İlimler Dergisi 5/1 (2010), 11.

99 bk. Bedia Akarsu, Felsefe Terimleri Sözlüğü (İstanbul: İnkılâp Kitabevi, ts.), 161; Zeynep Korkmaz, Gramer Terimler Sözlüğü (Ankara: Türk Dil Kurumu Yayınları, 1992), 136.

100 https://sozluk.gov.tr/ Erişim Tarihi: 18.07.2021.

101 Anlama ve yorumlama yöntemi olarak alegori, kutsal metinlerdeki saçma ve tarihsel olarak gerçekleşmesi imkansız rivayetlere bir takım batini anlamlar yükleyerek yorumlama çabasıdır. bk. Muhammed Tarakçı, “Origen ve Alegorik Kitab-ı Mukaddes Yorumu”, Uludağ Üniversitesi İlahiyat Fakültesi Dergisi 19/1 (2010), 209.

102 bk. Hans-Georg Gadamer, Hermeneutik I: Wahrheit und Methode (Gesammelte Werke Band 1) (Tübingen: J.C.B. Mohr (Paul Siebeck), 1990), 78-87; Matthias Jung, Hermeneutik Zur Einführung, (Hamburg: Junius Verlag, 2012), 35-38.

103 Berat Açıl, “Bir Tür mü Tarz mı? Klasik Türk Edebiyatında Alegori”, Dîvân Disiplinlerarası Çalışmalar Dergisi 19/37 (2014), 145. 
de tanımlanan ${ }^{104}$ alegorik anlatımı bir öğretim metodu olarak, nüansları mahfuz kalması şartıyla somutlaştırma ve temsil üslubuyla karşılamak mümkün görünmektedir. ${ }^{105}$ Dolayısıyla Sünnet'in niteliğini/neliğini belirlemede alegorik anlayıșın problemli olduğu ama belirlenmiş olan Sünnet'in öğretilmesinde bir anlatım tekniği olarak tıpkı temsili veya somutlaştırma üslubu gibi değerlendirilebileceği ve faydalanılabileceği söylenebilir. Nitekim alegoriyi, fikirlerin betimlemeler aracılı̆̆ıla ifade edilişi şeklinde tanımlayıp temsili anlatımın Batı'daki versiyonu olarak gören değerlendirmeler de söz konusudur. ${ }^{106}$

Sünnet'in halka arzını esas itibariyle bir eğitim-öğretim faaliyeti olarak görmek ve büyük ölçüde genel öğretimin ilke ve metotlarıyla icra edileceğini ama kendine has ilave bazı hususiyetlerinin olduğunu kabul etmek icap eder. Bunlar arasında öne çıkan yöntemlerin başında temsili anlatım gelmektedir. Bir öğretim metodu olarak temsili anlatımı eğitimciler şöyle tanımlamaktadırlar: "Temsil, anlaşılması güç bir durumu, daha belirgin ve çok bilinen benzeri ile anlatmaktır. Soyut kavramların somut olaylarla canlandırılıp şekillendirilmesi de bir temsildir. İnsanların kavramakta zorlandıkları soyut kavramları onlara anlatabilmenin en kolay yolu, somut olaylardan veya varlıklardan benzerlerini bulup temsil göstermek suretiyle anlatmaktır. Bazı bilgileri daha etkili ve çarpıcı bir şekilde sunmak ve zihinlerde yer etmesini sağlamak için de yine temsile baş vurulur."107 Çünkü ne kadar çok duyu organı eğitim-öğretime dahil edilebilirse verilmek istenen muhteva ve mesajın o ölçüde etkili ve kalıcı olacağı bilimsel olarak da ortaya konulmuştur. ${ }^{108}$ Hassaten temsili anlatım, somutlaștırma ya da metaforik metodun, "akılda kalıcılık, üretkenlik, yaratıcılığı geliştirme, farklı açıdan bakma, somutlaştırma, dikkat ve ilgi çekme, eğlendirme, düşünmeye teşvik, daha kolay öğrenme, anlaşılmayı kolaylaştırma, ezbersiz eğitim, aktif katılım, hayata aktarma, uygulama ve hayat gücünü geliştirme gibi 16 farklı sınıflandırmaya tabi tutulabilecek etkileri" nin olduğunun tespiti109 fevkalade önemlidir.

Temsili, somutlaştırma ya da metaforik üslubun araştırmayla ortaya konan bu 'öğreticilik/didaktiklik' özelliğinin ne kadar önemli olduğunu esasen Ahmed Yesevî'den Yunus Emre'ye Anadolu irfanî geleneğin geniş halk kitleleri nezdinde

104 bk. Adnan Altun - Mustafa Safran, Tarih Nasıl Öğretilir (İstanbul: Yeni İnsan Yayınları, 2019), 335.

105 Berat Açl, mecaz, istiare, metafor ve sembol kavramlarının alegori ile karıștırıldığını, oysa aralarında nüanslar bulunduğunu ve alegorinin Türkçedeki karşılığının temsili istiare olduğunu ileri sürmektedir. bk. Açıl, "Bir Tür mü Tarz mı? Klasik Türk Edebiyatında Alegori”, 149-152.

106 bk. Kılıç, "Kur'an ve Hadislerde Temsili Anlatım Örnekleri - İnsanî, İlahî ve Uhrevî Hakikatlerin Sunumu Bağlamında Semantik ve Pedagojik Bir Deneme", 16.

107 bk. Suat Cebeci, Etkili Din Öğretimi (İstanbul: Türkiye İlahiyat Tedrisatına Yardım Eden Dernekler Federasyonu/Tidef, 2010), 325.

108 Mesela bk. Nuray Senemoğlu, Gelişim Öğrenme ve Öğretim Kuramdan Uygulamaya (Ankara: Gönül Yayıncıllk, 2007), 388.

109 bk. Muharrem Atabay - Adem Güneș, "Din Öğretiminde Metafor Tekniğine Dayalı Kavram Öğretimi 'DKAB Dersi 11. Sınıf 3. Ünite Örneği'”, Uluslararası Sosyal Araştırmalar Dergisi 14/76 (2021), 739. 
asırları aşan etkisinde görmek mümkündür. Zira her seviyeden insanın rahatlıkla anlayabileceği bir sadelikte şekil-mânâ dengesini gözeten ve soyut kavramları somutlaştırarak anlatan bu üslup halkın idrakini kolaylaştırmış ve ilgisini celp etmiştir. Örneğin Mevlânâ Kalp huzuru olmadan namazın tam olamayacağını anlatırken Nebî'nin (sav) "Allah, kula namazda sağa sola iltifat etmedikçe rahmetiyle yaklaşmaya devam eder. Ama sağa-sola döndüğünde ondan yüz çevirir."110 hadisine atıf yapmakta, ardından buğday-fare metaforuyla amel-ihlas birlikteliğine herkesin anlayabileceği bir üslupla dikkati çekerek namaz özelinde ibadetleri bereketli buğdaya ve riya-kibir gibi manevi hastalıkları da fareye benzetmekte, ambarda yani amel defterinde biriktirilmeye çalışılan buğdayın hırsız fareye yani kalp hastalıklarına kurban edilmemesini öğütlemektedir. ${ }^{111}$ Yine o tek başına sözlü duanın yeterli olmayacağını, ihlaslı ve samimi olarak eldeki imkanları seferber etmek yani kavlî ve fiilı̂ duayı birlikte yerine getirmek gerektiğini de şöyle anlatmaktadır: "Öyleyse kuru duayı bırak a iyi talihli! Ağaç yetiştirmek için tohum saçmak gerek! Tohumun yoksa, Allah o dua yüzünden sana 'Ne de güzel çalıșmıș' dedirtecek bir fidan bağıșlar. Tıpkı Meryem gibi... Derdi vardı da tohumu yoktu hani. Hüner sahibi Allah o fidanı yeşertiverdi." 112 Anlamı bilinmeden Kur'ân tilavetinin aynen içindeki lezzetten ve gıdadan habersiz bir şekilde kırılmamış cevizin kabuğuyla oynayan çocuğun durumu gibi olduğunu anlatan temsili de aynı kabildendir. ${ }^{113}$

Tasavvufî anlatılarda öteden beri yaygın bir șekilde kullanılan metaforik ya da mecâzî yöntemin Mevlânâ'daki öne çıkan hususiyeti, kozmolojik ve somut teşbihlerin esas alınmış olmasıdır. Hatta onun anlatılarının ve düşüncesinin evrensel boyutta ilgi görmesinde en önemli özelliğin bitkiler, hayvanlar, dağlar, denizler, güneş ve yıldızlar gibi her çağda ve her coğrafyada bütün insanların iç içe yaşadığı kainattaki somut varlıklar ve olaylar üzerinden yaptığı somutlaştırma olduğunu söylemek mümkündür. Örneğin adaleti ve zulmü şöyle anlatır: Adalet nedir? Ağaçlara su vermek. Zulüm nedir? Dikene su vermek. Adalet bir nimeti yerli yerine koymaktır; su çeken her köke su vermek değil. Zulüm nedir? Bir şeyi uygunsuz yere koymak; buysa ancak belâya kaynak olur. Hakk'ın nimetini cana ve akla ver. Karnı burulmuş, düğümlenip kalmış tabiata değil."114 Soyut bir değer olan adalet kavramının her iklimden, dönemden ve seviyeden insanın yakinen bildiği bitkilerle izahının fevkalade akılda kalıcı olduğunda tereddüt yoktur.

Aynı şekilde eserlerinde toplu ya da dağınık bir şekilde yer almayan ama

\footnotetext{
110 Ebû Dâvûd, "Salât”, 165; Ebû 'Abdirraḥmân Aḥmed b. Şu'ayb b. 'Alî en-Nesâî, el-Müctebâ mine'ssüneni 'an Rasûlillah (Riyad: Dâru's-Selâm, 1419), "Sehv", 10.

111 bk. Mevlânâ, Mesnevî, 1/57-58 (375-389. Beyitler).

112 Mevlânâ, Mesnevî, 5/103 (1188-91. beyitler).

113 bk. Celâleddîn Muhammed b. Muhammed er-Rûmî Mevlânâ, Fîhî Mâ Fîh, çev. Meliha Ülker Anbarcıoğlu (İstanbul: Ataç, 2020), 115.

114 Mevlânâ, Mesnevî, 5/97 (1089-92. beyitler).
} 
“Mevlânâ'nın yedi ögüdü" olarak evrenselleşen erdemlerin, kozmik temellendirmeleri haiz teşbihler olduğu görülmektedir. ${ }^{115}$ Cihanşümul bir Peygamber olan $\mathrm{Hz}$. Muhammed'in mesajının da aynı şekilde küresel bir dil ve üslupla sunulmasını esas aldı̆̆ı görülen Mevlânâ'nın, Sahîhayn'da da yer alan “İnsanlar madenler gibidir..."116 hadisine dair yorumlarında takip ettiği temsili üslup ${ }^{117}$ ile Kur'ân'da ve hadislerde insanın en büyük zaaflarından birisi olarak işaret edilen ve irfanî anlayışın da en temel hedefi sayılan nefsin terbiyesi ve hırsın kontrol altına alınması meselesini muhteşem öküz metaforuyla somutlaştırması ${ }^{118}$ da hep kozmik temellendirme örnekleridir. Mesnevi'deki somutlaştırmada kullanılan teşbihler ve temellendirmeler tamamen gündelik hayatın akışı içerisinde doğada karşılaşılan somut varlıklar üzerine bina edilmiş ve her seviyeden insanın anlayabileceği sadelikte anlatılmıştır. Örnek kabilinden zikrettiğimiz bu misallerdeki kozmik somutlaştırmaları Mevlânâ'nın bütün yorumlarında görmek mümkündür.

Rasûlullah'ın (sav) değişmeyen ve karaktere dönüşmüş davranışlarından oluşan Sünnet'inin toplumda ete-kemiğe bürünmesine gayret gösterirken merkeze muhatapları yerleştiren Mevlânâ, kullandığı üsluba yöneltilebilecek muhtemel eleştirilerin de olabileceğini düşünmüş olacak ki "Halka bundan fazlasını söylemek uygun değil; deniz ırmağa sığmaz. Akıllar ölçüsünde, aşağıdan söylüyorum; ayıp değil ya, peygamberin de yaptığı budur"119 diyerek bu yöntemin sünnet olduğunu da ifade etmiş olmaktadır. Hatta bununla da yetinmeyerek Sünnet'in halka arzında muhatapların esas alınması gerektiğini şöyle dile getirir: "Vuslat adamı bir delilden söz ederse, ancak muhatapların anlaması için söz eder. Aklı dünyanın hesabını yapsa da baba çocuğu için çocukça sözler söyler. Hoca, (hiç noktası yok anlamında) elif tamtakırdır derse, erdeminden bir şey eksilmez. Dili açılmamış kimseye bir şeyler öğretmek için (hocanın) kendi dilinden çıkması gerek. Senden ilim ve ustalık öğrensin diye onun anladığı dilden konuşmak gerek. Öyleyse hoca/şeyh öğüt verirken bütün insanlar onun çocukları gibi olmalı... Çünkü söz, dinleyenin değerincedir (dinleyene göre söylenir); terzi adamın boyuna göre kaftanı biçer."120

Özetle somutlaştırma, insanın algılayabildiklerinden hareketle algılayamadığını kavratmak ya da bir başka ifadeyle insanın duyularıyla dokunup görebildiği âlem vasıtasıyla insanın iç dünyasında var olan ama elle tutulup gözle görülmeyen âlemin idrakine vardırmak çabasıdır. Bu üslup sayesinde hem ilahî hakikat ve hik-

\footnotetext{
115 bk. Cafer Sadık Yaran, “'Mevlânâ'nın Yedi Öğüdü’: Evrensel Erdemler, Kozmik Temellendirmeler ve Aidiyet Meselesi", İstanbul Üniversitesi İlahiyat Fakültesi Dergisi 16 (2007), 21-48.

116 Buhârî, "Enbiyâ", 2; Müslim, "Birr”, 160.

117 bk. Mevlânâ, Mesnevî, 2/129 (2053-2083 arası beyitler); Celâleddîn Muhamamed b. Muhammed erRûmî Mevlânâ, Dîvân-ı Kebîr, çev. Abdulbâkî Gölpınarlı (Eskişehir: Kültür Bakanlığı Yayınları, 1992), 7/287 (3667-3671. arası rubailer).

118 Mevlânâ, Mesnevî, 5/212-213 (2855-2869. beyitler).

119 Mevlânâ, Mesnevî, 1/265 (3810-11. beyitler).

${ }^{120}$ Mevlânâ, Mesnevî, 2/203 (3300-3305. beyitler), 6/95 (1241. beyit).
} 
metlerin daha etkili aktarılması hem de verilmek istenen mesajların daha geniş kitlelere ulaşması kolaylaşacaktır. Çocukların öğrenimlerinin ergenlik dönemine kadar büyük oranda somut olaylar-olgular üzerinden gerçekleşmesi ve yetişkinler için de 'şimdi ve burada'nın çok etkili olduğu düşünüldüğünde inanç ve erdemlerin topluma sunumunda somutlaştırmanın önemi daha iyi anlaşılacaktır.

\section{Sonuç}

Son dönemlerde hadisin ve/veya Sünnet'in çağa taşınması, asrın idrakine söyletilmesi ya da aktüel hale getirilmesi gibi isimlendirmelerle ortaya konan çabaların ve çalışmaların, birisi taşınacak olanın neliği ve diğeri de nasıl taşınacă̆ı olmak üzere iki yönü bulunmaktadır. Kütüb-i sitte başta olmak üzere temel hadis kitapları ve bunlar etrafında oluşan hadis ve sünnete dair devasa literatür büyük oranda "hadis-sünnetin neliği" ile ilgili olup günümüz diliyle akademik çalışmalardan oluşmaktadır. Şerhler de dahil olmak üzere bunlar tamamen ulemanın birbirlerine aktaracakları bilgileri ihtiva etmekte ve istifade etmek için belirli bir ilmi altyapıya ihtiyaç duyulmaktadır. İlm-i hadisin tarihini, terminolojisini ve literatürünü okumayanların, tercümeleri vasıtasıyla -ki tercümelerini doğru ve faydalı bulmuyoruzsöz konusu eserleri doğru anlama imkanları yok denecek kadar azdır.

İslami ilimlerin diğer dallarında olduğu gibi ilm-i hadisin de dinin temel maksadına muvafik olarak nihai hedefinin insanların dünyada ve ahirette huzurunu temin etmek olduğunda şüphe yoktur ki bu da Sünnet'in çağa nasıl taşınacağı sorununu gündeme getirmektedir. Son yıllarda birden fazla uluslararası kuruluşça düzenli bir şekilde yayımlanan yolsuzluk endekslerinde İslam dünyasının hiç de parlak olmayan durumu, bu nihâî gaye için ciddi yeni çalışmaların yapılmasını zorunlu kılmaktadır. Bu maksadın gerçekleşebilmesi için ister hadis ve sünnetin aktüel değeri denilsin, ister sünnetin çağa yakınlaştırılması ya da taşınması densin ve isterse asrın idrakine sünnetin söyletilmesi veya sunulması densin okulda öğrencileri, camide cemaati ve cami dişı farklı faaliyetlerde ya da sosyal medya mecralarında halkı Hz. Peygamber'in örnekliğiyle ve rehberliğiyle buluşturmaya çalışan (tıbbi ifadeyle) pratisyenlere başucu veya el kitabı olabilecek çalışmalara ihtiyaç vardır. Bu tür çalışmalar, yeterliği bir tarafa Riyâzu's-sâlihîn tarzı geçmişte yazılan sınırlı sayıdaki eserler gibi, akademik literatürde üretilmiş soyut hedefleri somut hale getirmek suretiyle öğretimi doğrudan yönlendiren ve öğretmenin bulunmadığı durumlarda onun görevini yerine getiren ders kitapları gibi merkeze ortalama okurları almalıdır. Dil sorunundan ayrı olarak, klasik kaynakların tercümeleri ile belirli bir kitap üzerine yapılan çağdaş birkaç şerhin bahis konusu niteliği haiz olmadığı açıktır. Diyanet İşleri Başkanlığınca özgün, kolektif ve konulu ilk çağdaş hadis şerhi olarak hazırlanan Hadislerle İslam'ın mezkûr ihtiyacın karşılanmasında çok büyük bir adım olduğu inkâr olunamaz. Hatta Hz. Peygamber'in örnekliğinin ve rehberliğinin günümüze nasıl taşınacağı ve geniş halk kitlelerine nasıl sunulacağı ve davranışlara dönüştürüleceği sorununa hedef kitle olarak sevâd-ı azamı teşkil 
eden ortalama okurları seçerek çare olmak üzere somut olarak ortaya konan yegâne çalışma Hadislerle İslam'dır. Gerek sahip olduğu evsaf itibariyle çağdaş dönemde telif edilen ilk çalışma olan bu eserin gerekse bundan sonra telif edilecek benzer kitapların daha faydalı hale gelebilmesine yönelik mütevazi katkılarımızı birkaç madde halinde sunmak istiyoruz.

a. Öncelikle hicri ilk asırlardaki ehl-i re'y ile ehl-i amel ekollerinin yaptığı gibi hadis-sünnet ayırımına gidilmeli, ortalama okurlara hadisten ziyade kısaca $\mathrm{Hz}$. Peygamber'in örnekliği ve rehberliği diyebileceğimiz Sünnet arz edilmeli, hadis ise bu sünnetin sonraki nesillere taşıyıcısı ya da sünnetin veri tabanı ve ham bilgi deposu mesabesinde görülerek uzmanlarının değerlendirmelerine bırakılmalıdır. Çünkü hadisler, hadis, rivayet, ravi, sahih, zaylf, mevzu'/uydurma gibi tamamen teknik terimler kullanılmadan aktarılamayacağından herhangi bir dini ilim altyapısı olmayan insanlar hadislerle karşı karşıya getirilmeden ve de Hz. Peygamber'i örnek alma ve ona uyma konusunda hadisin referansına muhtaç etmeden doğrudan ve yalnızca Sünnet'in idraklere sunulmasına gayret edilmelidir. Söz ıssı Rasûl-i Ekrem'in (sav) sıhhati ve delaleti sarih olan cevâmi'u'l-kelim nitelikli ve hikmet dolu ya da doğrudan bir sünneti ifade eden hadislerinin arzıyla yetinilmelidir. Ayrıca her ne kadar klasik kaynaklarda mevzu hadis ifadesi kullanılıyor olsa da ihtiyaç miktarınca hadislerin halka arzında uydurma hadis yerine uydurma rivayet tabirinin tercih edilmesinin daha doğru olacağını belirtmek isteriz. Bu meyanda Hadislerle İslam adlandırması, muhtevası bir tarafa en azından söylem olarak, Ayetlerle İslam ve modern selefilik gibi farklı anlayışlara meşruiyet kazandırabileceğinden sorunlu olup bu gibi hadis vurgulu adlandırmalardan kaçınmak gerekir.

b. Mehabet ve bütünlük açısından müekked-gayr-i müekked sünnet, farz/vacip-sünnet, bağlayıcı olan-olmayan sünnet gibi kategorik ve iltibasa müsait değerlendirmeler ulemanın mütalaasına terkedilmeli, halka arzda tıpkı ilk nesillerde olduğu gibi hem mendubu/nafileyi ve vacibi/farzı içine alacak şekilde hem de bağlayıcılık sorunu giderilmiş bir vaziyette Sünnet'in bir zihniyet ve dünya görüşü olarak takdimi sağlanmalıdır.

c. Fetva-takvâ, hukukilik-kanunilik ya da helallik-yasallık gibi çağımızın ciddi dilemmasından sıyrılabilmek için Sünnet'in arzında, örneğin ibadetlerin bedene taalluk eden suretlerini fikıh kitaplarına ve mânevî ya da bâtinî boyutlarını da tasavvufî eserlere bırakıp daha ziyade rivayet merkezli bir terğîb-terhîb muhtevalı şerh-yorum takip etmek yerine, Ahmed Yesevî'den Mevlânâ'ya Anadolu irfan geleneğinin şekil-mânâ ve sûret-ruh dengeli anlayışı benimsenmelidir.

d. Sünnet'in halka arzı esas itibariyle bir eğitim-öğretim faaliyeti olduğundan büyük oranda soyut kavramlardan oluşan adalet, dürüstlük, kul hakkı ve takva gibi değerler ve erdemler, Kur'ân ve Sünnet'in temel anlatım üslupları arasında yer alan somutlaştırma ve kozmik temellendirme üslubuyla izah edilmelidir.

e. Ergenlik dönemi sonuna kadar çocukların öğreniminin somut olaylar- 
olgular üzerinden gerçekleștiği dikkate alınarak tıpkı Bibel für Kinder/Çocuk İncili gibi Batı'da hazırlanan ve bir benzerini De Koran; Uitleg Voor Kinderen/Çocuklar Íçin Açıklamalı Kur'ân adıyla Abdulwahid van Bommel'in yaptığı tarzda somutlaştırma üslubuna dayalı Çocuklar İçin Sünnet kitapları telif edilmelidir.

Funding / Finansman: This research received no external funding. / Bu araștırma herhangi bir diş fon almamıștır.

Conflicts of Interest / Çıkar Çatışması: The author declare no conflict of interest. / Yazar, herhangi bir çıkar çatışması olmadı̆̆ını beyan eder.

\section{Kaynakça}

Acâc, Muhammed. es-Sünne kable't-tedvîn. Kahire, 1971.

Acar, Yusuf. "Fukahanın Amel Etmediği Bazı Sahîhayn Hadisleri ve Buhârî ile Müslim'in Bunlara Yaklașım Farkı / Some Șahīhāyn Hadiths That the Fuḳahā’ Have not Put into Practice and the Difference Between Bukhārī and Muslim's Approach to Them". Hadith 4, 10-50. https://doi.org/doi.org/10.5281/zenodo. 3965830.

Acar, Yusuf. "Zayıf Hadisin Amel Karinesiyle Desteklenmesi ve Tirmizî'nin Süneni". Necmettin Erbakan Üniversitesi İlahiyat Fakültesi Dergisi [Selçuk Üniversitesi İlahiyat Fakültesi Dergisi 37 (2014), 41-69.

Açık, Abdullah. Temel Dini Bilgiler (İslam 2) Ortaöğretim Ders Kitabı. ed. Mustafa Yılmaz. Ankara: Milli Eğitim Bakanlığı Devlet Kitapları, 2019. https://drive.google.com/file/d/1mTU8m39vNe0y0KkpnijH7R3K2XAAT5Lz/view

Açıl, Berat. "Bir Tür mü Tarz mı? Klasik Türk Edebiyatında Alegori". Dîvân Disiplinlerarası Calışmalar Dergisi 19/37 (2014), 145-167.

Agitoğlu, Nurullah. "Sünnetin Doğru Anlaşılması ve Günümüze Taşınması -'Allah Güzeldir, Güzelliği Sever' Rivâyeti Üzerine Bir Değerlendirme”. Illahiyat Akademi Dergisi: Altı Aylık Uluslararası Akademik Araştırma Dergisi 7-8 (2018), 339-351.

Ağırman, Cemal. "Hadisçilerin Sünnet/Hadis Tarifinde Yer Alan Vasıf Kavramı Üzerinde Bir Yorum". Cumhuriyet Üniversitesi İlahiyat Fakültesi Dergisi 2 (1998), 99-121. http://isamveri.org/pdfdrg/D01956/1998_2/1998_2_AGIRMANC.pdf

Ahatlı, Erdinç. "Cumhuriyet Dönemi Türkçe Hadis Şerhlerine Dair Bazı Mülahazalar -Ebû Dâvûd, İbn Mâce ve Dârimî Şerhleri Üzerine Bir Analiz-". Hadis Tetkikleri Dergisi 6/2 (2008), 7-30. http://isamveri.org/pdfdrg/D02568/2008_2/2008_2_AHATLIE.pdf

Ahatlı, Erdinç. "Hadis İlminde Metodoloji Problemleri". İslâmî İlimlerde Metodoloji/Usûl Mes'elesi II. 801-814. İstanbul: Ensar Neșriyat, 2005.

Ahatlı, Erdinç. "Klasik ve Cumhuriyet Dönemi Hadis Şerhçiliği: Şekil ve Muhteva Açısından Bir Mukayese". Íslam ve Klasik. İstanbul, 2008.

Akarsu, Bedia. Felsefe Terimleri Sözlügü. İstanbul: İnkılâp Kitabevi, 6. Basım, ts.

Alatlı, Alev. "Her yasal olan hak helal değildir. Mühim olan helalleşmektir.", 2016. https://www.youtube.com/watch?v=LqmLvYczdg0

'Allûş, Ebû 'Abdillâh 'Abdusselâm Muhammed 'Ömer. el-İntihâ' li ma'rifeti'l-ehâdîs elletî lem yefti bihâ'l-fukahâ ve münâkașetühâ 'alâ żav'i'l-ușûliyyîn ușûli'l-fikh ve ușûli'l-hadîs. Beyrut: Dâru İbn Hazm, 1996.

Altun, Adnan - Safran, Mustafa. Tarih Nasıl Öğretilir. İstanbul: Yeni İnsan Yayınları, 2019.

Ankaravî, İsmail Rusûhî. Mesnevî-i Şerif Şerhi. İstanbul, 1289.

Aslan, Recep. Sünnet ve Sünnetin Günümüze Taşınması. İstanbul: Ensar Neşriyat, 1. Basım, 2020.

Atabay, Muharrem - Güneș, Adem. "Din Öğretiminde Metafor Tekniğine Dayalı Kavram Öğretimi ‘DKAB Dersi 11. Sınıf 3. Ünite Örneği'”. Uluslararası Sosyal Araştırmalar Dergisi 14/76 (2021), 720-739.

Bayraktutar, Muammer. "İmam Şâfiî̀nin Hadisleri Anlama ve Yorumlama Yöntemi". Marife 21/2 (2021): 833-869 
Gelenekselci ve Modernist Paradigmalar Kıskacında Imam Şâfiî. ed. Mahfuz Söylemez. 109-138. Ankara: Araștırma Yayınları, 1. Basım, 2014.

Bedir, Murtaza. "Sünnet". Türkiye Diyanet Vakfı İslâm Ansiklopedisi. 38/150-153. İstanbul: TDV Yayınları, 2010.

Buhârî, Ebû 'Abdillâh Muhammed b. 'İsmâîl b. İbrâhîm el-Cu'fî. el-Câmi'u'l-müsnedü'ṣșahîhu'l-muhtașar min umûri Rasûlillâhi șallallâhü 'aleyhi ve sellem ve sünenihî ve eyyâmih. thk. Muhammed Züheyr b. Nâșır. 9 Cilt. Beyrut: Dâru Tavkı'n-Necât, 1. Basım, 1422.

Burhan Toprak. Yunus Emre Divanı. Eskişehir: Odunpazarı Belediyesi, 3. Basım, 2006.

Buz, Funda - Erul, Melike Rana. "Sosyoekonomik Gelişmişlik Düzeyinin Yolsuzluk Algı Endeksi Üzerindeki Etkisine İlişkin Bir Analiz". International Journal of Public Finance 3/2 (2018), 233-248. https://dergipark.org.tr/tr/download/articlefile $/ 613544$

Cebeci, Suat. Etkili Din Öğretimi. İstanbul: Türkiye İlahiyat Tedrisatına Yardım Eden Dernekler Federasyonu/Tidef, 3. Basım, 2010.

Coşkun, Selçuk. Hadise Bütüncül Bakış. İstanbul: İFAV, 3. Basım, 2016.

Çakan, İsmail Lutfi. Hadis Usulü. İstanbul: İFAV, 3. Basım, ts.

Dârimî, Ebû Muhammed 'Abdullah b. 'Abdirrahmân b. el-Faḍl. es-Sünen. thk. Hüseyin Selim Esed. 4 Cilt. S. Arabistan: Dârü'l-Muğnî, 1. Basım, 2000.

Demirci, Selim. "Hadis Metnini Anlama/Somutlaştırma Çabasına Bir Örnek: Hz. Peygamber'in Emel-Ecel İlișkisine Dair Çizdiği Șekil”. FSM İlmi Araștırmalar İnsan ve Toplum Bilimleri Dergisi 6 (2015), 101-121.

Dihlevî, Şâh Veliyyullah. Huccetullâhi'l-bâligia. thk. Muhamamed Şerif Sükkar. 2 Cilt. Beyrut: Dâru İhyâi'l-Ulûm, 1990.

Döndüren, Hamdi. İslam İlmihali. İstanbul: Erkam Yayınları, 1. Basım, 1991.

Ebû Dâvûd, Süleymân b. el-Eş'aș b. İshâk es-Sicistânî el-Ezdî. es-Sünen. Riyad: Dâru's-Selâm, 1. Basım, 1419.

Ebû Zehv, Muhammed. el-Hadîs ve'l-muhaddisûn. Beyrut, 1984.

Efendioğlu, Mehmet. "Şerh". Türkiye Diyanet Vakfi İslâm Ansiklopedisi. C. 38. İstanbul: TDV İslâm Araştırmaları Merkezi, 2010. https://islamansiklopedisi.org.tr/serh\#3-hadis

Erkaya, Musa. “Hz. Peygamber (s.a.v)'in Örnek Ahlâkının Günümüze Taşınmasında Hadis/Sünnetin Rolü”. 7-8 Mayıs 2010 Modern Çağda Ahlak Sempozyumu. 327-364. Konya: Sebat Ofset Matbaacılık, 2012.

Erul, Bünyamin. Sahabenin Sünnet Anlayışı. Ankara: TDV, 1. Basım, 1999.

Erul, Bünyamin. Sünnet Kavramı ve Sekaleyn Rivayetleri. Ankara: İlahiyat Yayınları, 2007.

Evgin, Abdulkadir. "Hadis'e Dayalı Bazı Problemlerin Günümüze Yansımaları". Dinî Araştırmalar Dergisi 5/13 (2002), 177-186.

Fazilet Neşriyat (ed.). Resimli Muhtasar İlmihal. İstanbul: Fazilet Neşriyat ve Ticaret A.Ş., 2020.

Gadamer, Hans-Georg. Hermeneutik I: Wahrheit und Methode (Gesammelte Werke Band 1). Tübingen: J.C.B. Mohr (Paul Siebeck), 6. Basım, 1990.

Görmez, Mehmet. "Din ve Dindarlık”. Diyanet Aylık Dergi 265 (Ocak 2013): 1-3.

Görmez, Mehmet. Sünnet ve Hadisin Anlaşılması ve Yorumlanmasında Metodoloji Sorunu. Ankara: TDV Yayınları, 1. Basım, 1997.

Guraya, Muhammed Yusuf. Sünnetin Neliği Sorununa Metodik Bir Yaklaşım -Mâlik'in Muvatta Örneğinde-. çev. Mehmet Emin Özafşar. Ankara: Ankara Okulu, 1. Basım, 1999.

Hațîb el-Bagdâdî, Ebû Bekr Ahmed b. 'Alî. Nașîhatü ehli'l-hadîis. thk. 'Abdülkerîm Aḥmed elVerîkât. Zerkâ: Mektebetu'l-Menâr, 1. Basım, 1408.

Hatiboğlu, İbrahim. "Hadis ve Sünnet Terimlerine Farklı Bir Yaklaşım: Fazlurrahman'ın Hadis ve Sünnet Ayırımı". Marife 1/1 (2001), 33-47.

İbn 'Abdilberr, Ebû 'Omer Yûsuf b. 'Abdillâh b. Muhammed b. 'Abdilberr en-Nemerî. Câmi'u beyâni'l-'ilm ve faḍlih ve mâ yenbagî fî rivâyetih ve hamlih. thk. Ebü'l-Eşbel ezZüheyrî. 2 Cilt. Suudiarabistan: Dâru İbni'l-Cevzî, 1. Basım, 1994.

İbn 'Abdilberr, Ebû 'Omer Yûsuf b. 'Abdillâh b. Muhammed b. 'Abdilberr en-Nemerî. elMarife 21/2 (2021): 833-869 
'Ístizkâru'l-câmi' li-mezâhibi fukahâi'l-emșâr ve 'ulemâi'l-aktâr fîmâ tedammenehü'lMuvatța min me'âni'r-re'y ve'1-âsâr ve șerhu zâlike küllih bi'l-îcâzi ve'l-ihtișâr. thk. Sâlim Muhammed 'Ata, Muhammed 'Ali Mu'avvad. 9 Cilt. Beyrut, 1. Basım, 2000.

İbn Mâce, Ebû 'Abdillâh Muhammed b. Yezîd Mâce el-Kazvînî. es-Sünen. Riyad: Dâru's-Selâm, 1. Basım, 1419.

Jung, Matthias. Hermeneutik Zur Einführung. Hamburg: Junius Verlag, 2012.

Kahraman, Abdullah. "Yunus Emre Dîvân'ında Şerîat, Tarîkat, Hakîkat ve Marîfet (Dört Kapı)”. Kocaeli Illahiyat Dergisi 1/1 (2017), 1-18.

Karaman, Hayrettin. "Bağlayıcılık Bakımından Rasûlullah'ın Davranıșları”. Hz. Peygamber ve Aile Hayatı. İstanbul: İlmî Neşriyat. Erişim 09 Temmuz 2021. http://isamveri.org/pdfdrg/D105154/1989/1989_KARAMANH.pdf

Karaman, Hayrettin. Hadis Usulü. İstanbul: Ensar, 11. Basım, 2014.

Kâasimî, Muḥammed Cemâlüddîn b. Muḥammed el-. Kavấ'ıü't-taḥdîs min fünûni mușțalaḥı'lhadîs. Beyrut: Dâru Kütübi'l-İlmiyye, ts.

Keleș, Ahmet. Sünnet -Yeni Bir Usul Denemesi-. İstanbul: İnsan Yayınları, 3. Basım, 2015.

Kılıç, Sâdık. "Kur'an ve Hadislerde Temsili Anlatım Örnekleri - İnsanî, İlahî ve Uhrevî Hakikatlerin Sunumu Bağlamında Semantik ve Pedagojik Bir Deneme". İslâmî İlimler Dergisi 5/1 (2010), 11-40.

Kırbaşoğlu, M. Hayri. İslam Düşüncesinde Hadis Metodolojisi. Ankara: Ankara Okulu, 1. Basım, 2000.

Kırbaşoğlu, M. Hayri. İslam Düşüncesinde Sünnet. Ankara: Ankara Okulu Yayınları, 2. Basım, 1996.

Kırbaşoğlu, M. Hayri. Sünneti Çağa Taşımak -Sünneti ve Hadisi Anlama ve Yorumlamada Yüntem-. Ankara: Ankara Okulu, 1. Basım, 2021.

Kırış, Şemsettin. "Yeni Sünnet Tanımları Bağlamında Sünnet-Dindarlık İlişkisi Üzerine Bazı Mülâhazalar". Hadis Tetkikleri Dergisi 15/2 (2017), 7-41. http://isamveri.org/pdfdrg/D02568/2017_2/2017_2_KIRISS.pdf

Koca, Ferhat. "Sünnet". 38/154-155. İstanbul: Türkiye Diyanet Vakfı İslam Araştırmaları Merkezi, 2010.

Koçkuzu, Ali Osman. Mesnevî̀de Hz. Peygamber -Hadis-i Şeriflere Atıflar-. Konya: Rûmî Yayınları, 1. Basım, 2006.

Koçyiğit, Ahmed Talat. Hadis Istılahları. Ankara: İlahiyat Yayınları, 1985.

Komisyon. TDV İlmihal. 2 Cilt. Ankara: Türkiye Diyanet Vakfı, 27. Basım, 2020.

Korkmaz, Zeynep. Gramer Terimler Sözlügü. Ankara: Türk Dil Kurumu Yayınları, 1992.

Köktaș, Yavuz. "Bazı Yeni Sünnet Tanımları Üzerine”. Dîvân İlmî Araștırmalar 7/12 (Ocak 2002), 95-160.

Ḳuşeyrî, 'Abdülkerim b. Hevâzin b. 'Abdülmelik. er-Risâletü'l-Kuşeyriyye. thk. 'Abdülḥalim Maḥmud, Maḥmud b. eş-Şerîf. 2 Cilt. Kahire: Dârü’l-Maârif, 1. Basım, ts.

Macit, Yusuf. "Kaçak Elektrik Olgusu: Dini, Ekonomik ve Psiko-Sosyal Açıdan Yaklaşım". Süleyman Demirel Üniversitesi Illahiyat Fakültesi Dergisi 32 (2014), 107-132. https://dergipark.org.tr/tr/download/article-file/794325

Mertoğlu, M. Suat. "Üslûbu'l-Kur'ân”. Türkiye Diyanet Vakfi İslâm Ansiklopedisi. 42/382. İstanbul: TDV Yayınları, 2012.

Mevlânâ, Celâleddîn Muhammed b. Muhammed er-Rûmî. Dîvân-ı Kebîr. çev. Abdulbâkî Gölpınarlı. 7 Cilt. Eskişehir: Kültür Bakanlığı Yayınları, 1992.

Mevlânâ, Celâleddîn Muhammed b. Muhammed er-Rûmî. Fîhî Mâ Fîh. çev. Meliha Ülker Anbarcıoğlu. İstanbul: Ataç, 10. Basım, 2020.

Mevlânâ, Celâleddîn Muhammed b. Muhammed er-Rûmî. Mesnevî. ed. Mehmet Birekul. çev. Derya Örs - Hicabi Kırlangıç. 6 Cilt. Konya: Konya Büyükşehir Belediyesi Yayınları No:125, 1. Basım, 2007.

Mustafa Yılmaz (ed.). Temel Dini Bilgiler (İslam 1) Ortaokul ve Imam Hatip Ortaokulu Ders Kitabı. Ankara: Milli Eğitim Bakanlığı Devlet Kitapları, 2019. https://drive.google.com/file/d/1JmxxzFffDVDwd37MKNfd0gD6Jnbdggmx/view

Müslim, Ebu'l-Ḥuseyn Müslim b. el-Ḥaccâc b. Müslim el-Kuşeyrî. el-Müsnedü'ṣ-șahîhhu'lMarife 21/2 (2021): 833-869 
muhtasar mine's-sünen bi nakli'l-adli ani'l-adl an Rasûlillâh sallallâhü 'aleyhi ve sellem. thk. Muhammed Fuad Abdülbâkî. 5 Cilt. Beyrut: Dâru İhyâi't-Turâsi'l-Arabî, t.s.

Nayir, Sabahattin (ed.). Temel Dini Bilgiler (İslam 1) Ortaöğretim Ders Kitabı. Ankara: Milli $\begin{array}{llll}\text { Eğitim Bakanlığı } & \text { Devlet } & \end{array}$ https://drive.google.com/file/d/147T_JCQUCY2dA5od3HnqHDrtWGzpRx6X/view

Nesâî, Ebû 'Abdirraḥmân Aḥmed b. Şu'ayb b. 'Alî. el-Müctebâ mine's-süneni 'an Rasûlillah. Riyad: Dâru's-Selâm, 1. Basım, 1419.

Nevevî, Ebû Zekeriyyâ Yahyyâ b. Şeref b. Mürî. Riyâzü's-sâlihîn. thk. Şuayb el-Arnavut. Beyrut: Müessesetü'r-Risâle, 3. Basım, 1998.

Özafşar, Mehmet Emin. "Hadis İlminde Alan Evrilmesi”. İslâmiyât 6/4 (2003), 105-120.

Özafşar, Mehmet Emin. Hadis ve Kültür Yazıları. Ankara: Otto Yayınları, 2. Basım, 2015.

Özafșar, Mehmet Emin. Hadisi Yeniden Düșünmek. Ankara: Ankara Okulu, 1. Basım, 1998.

Özafșar, Mehmet Emin. "'Hadisin Neliği' Sorunu ve Akademik Hadisçilik". İslâmiyât 3/1 (2000), 33-53.

Özafșar, Mehmet Emin - Recai Doğan (ed.). Temel Íslam Bilgileri -İbadetim-. Ankara: Diyanet İşleri Başkanlığı Yayınları, 3. Basım, 2009.

Özbaran, M. Hakan. "Yolsuzluk ve Bu Alanda Mücadele Eden Uluslararası Örgütler ve Birimler". Sayıștay Dergisi Temmuz-Aralık (2003), 17-34.

Özdemir, Ahmet. Temel Dini Bilgiler -Anadolu İmam Hatip Lisesi-. Ankara: Milli Eğitim Bakanlığı Devlet Kitapları, 1. Basım, 2018.

Özpınar, Ömer. Hadis Edebiyatının Oluşumu. Ankara: Ankara Okulu, 1. Basım, 2005.

Özșenel, Mehmet. İlk Dönem Hadis-Rey Tartışmaları Şeybânî Örneği. İstanbul: İFAV, 2. Basım, 2017.

Özüdoğru, Bekir. Rivayetlerin Hz. Peygamber'e Aidiyetini Tespitte Amel Olgusu. Samsun: Ondokuz Mayıs Üniversitesi, Sosyal Bilimler Enstitüsü, Doktora Tezi, 2018.

Sakallı, Talat. "Sünnet'in Bağlayıcılık Açısından Taksimi". Süleyman Demirel Üniversitesi Illahiyat Fakültesi Dergisi 2 (1995), 39-102. http://isamveri.org/pdfdrg/D01535/1995_2/1995_2_SAKALLIT.pdf

Salih, Suphi. Hadis İlimleri ve Hadis Istılahları. çev. Yaşar Kandemir. İstanbul: İFAV, 1996.

Senemoğlu, Nuray. Gelişim Öğrenme ve Öğretim Kuramdan Uygulamaya. Ankara: Gönül Yayıncllık, 2007.

Şahyar, Ataullah. “'Ey Fakihler Zümresi! Sizler Tabipsiniz, Bizler ise Eczaciyız!' Sözünün Tespiti ve Muhteva Değerlendirmesi”. Hadis Tetkikleri Dergisi 13/1 (2015), 75-94.

Şengül, İdris. "Kıssa”. Türkiye Diyanet Vakfı İslâm Ansiklopedisi. 25/498-501. İstanbul: TDV Yayınları, 2002.

Şentürk, Lutfi - Yazıcı, Seyfettin. İslam İlmihali. Ankara: Diyanet İşleri Başkanlığı, ts. https://diniyayinlar.diyanet.gov.tr/Documents/islam\%20ilmihali\%2017\%20X\%20 24\%20.pdf

Şimșek, Murat. İslam Hukukunda Bağlayıcılık Bakımından Hz. Peygamber'in İctihad ve Tasarrufları. Ankara: Türkiye Diyanet Vakfı, 1. Basım, 2010.

Tarakçı, Muhammed. "Origen ve Alegorik Kitab-ı Mukaddes Yorumu”. Uludă̆ Üniversitesi Illahiyat Fakültesi Dergisi 19/1 (2010), 183-213. http://isamveri.org/pdfdrg/D00193/2010_19_1/2010_XIX_1_TARAKCIM.pdf

Tirmizîi, Ebû 'Îsâ Muhammed b. 'Îsâ b. Sevre es-Sülemî. el-Câmi'u'l-muhtașar mine's-sünen an Rasûlillâh ve ma'rifetu'ș-șahîh ve'l-ma'lûl ve mâ 'aleyhi'l-'amel. thk. Beșşâr 'Avvâd Ma'rûf. 6 Cilt. Beyrut: Dâru'l-Ğ́arbi'l-İslâmî, 1. Basım, 1998.

Türcan, Zișan. Hadis Şerh Geleneği Doğuşu Gelişimi ve Dönüşümü. Ankara: TDV Yayınları, 1. Basım, 2011.

Uğur, Mücteba. Ansiklopedik Hadis Terimleri Sözlügü. Ankara: Türkiye Diyanet Vakfı, 1992.

Ulu, Arif. Tâbiûnun Sünnet Anlayıșı. İstanbul: İFAV, 1. Basım, 2015.

Ulutürk, Veli. "Kur'an-ı Kerim'de Meseller (Emsâlü'l- Kur'an) (I-II)". Atatürk Üniversitesi İlahiyat Fakültesi Dergisi 11-12 (1993-1995), 74-100 ve 29-48.

Ürkmez, Ahmed. "Sosyal Kesimler ve Sünnet Algıları Araştırması: Malatya (Hadis Alan Marife 21/2 (2021): 833-869 
Yorumu)". Süleyman Demirel Üniversitesi Illahiyat Fakültesi Dergisi 2012/1/28 (2012), 97-128.

Yaman, Ahmet. "Fakih ve Ahlâk - Fıkıh Etiği Üzerine Bazı Notlar -". Usûl İslam Araştırmaları Dergisi 26 (2016), 7-50.

Yaran, Cafer Sadık. "'Mevlânâ'nın Yedi Öğ̈̈ü': Evrensel Erdemler, Kozmik Temellendirmeler ve Aidiyet Meselesi". İstanbul Üniversitesi İlahiyat Fakültesi Dergisi 16 (2007), 21-48.

Yardım, Ali. Hadis I-II. İstanbul: Damla Yayınevi, 1. Basım, 2017.

Yazıcı, Seyfettin. Temel Dini Bilgiler. Ankara: Diyanet İşleri Başkanlığı Yayınları, 2012.

Yücel, Ahmet. Hadis Usulü. İstanbul: İFAV, 39. Basım, 2018.

Zihnî, Muhammed (Mehmed). Nimet-i Íslam. İstanbul: Şirket-i Mertebiye Matbaası, 13201897.

'Itr, Nûruddîn. Menhecu'n-nakd fî 'ulî'l-hadîs. Dimeșk: Dâru'l-Fikr, 3. Basım, 1981.

Hadislerle İslam. 7 Cilt. Ankara: Diyanet İşleri Başkanlığı, 4. Basım, 2017.

Yûnus Emre Dîvânı. Ankara: T.C. Kültür ve Turizm Bakanlığı Kütüphaneler ve Yayımlar Genel Müdürlüğü, ts. 